\title{
Denominations of the Egyptian God Ha
}

\author{
Walid Shaikh Al Arab
}

\begin{abstract}
Abstarct
The desert-god Ha had theologically integrated the ancient Egyptian religious beliefs from a very early period as he was mentioned in the main funeral corpus of the Pyramid and Coffin Texts as well. This survey aims to shed more light on thedifferent aspectsof $\mathrm{Ha}$ and the roles he played throughout ananalytical study of his formal and particular names and epithets from the Old Kingdom (2647-2150 BC) to the end of the Greco-Roman period (332 BC-642 AD). Named « H3: HA, H3-Imn-Wn-nfr: HA-Amon-Wen-nofre, H3 '3: Ha-the-Great, H3-m-Št3: Ha in Sheta, H3Spd:Ha-Soped, H3-Skr:Ha-Soker andHr-H3: Horus-HA », the desert-god Ha was described as «Nb Imntt: Lord of the West », «? phty: Great of might », «wr šfyt: Great of terror», «nb phty: Lord of might », «ntr mnh : Potent god », «shm dm pt: Puissance who touches the sky » and «kj?: High of arm », whose invincibility was thought to provide protection not only for Egypt especially the western deserts and their oases from enemies such as desert nomads, invading Libyan tribesmen, Asiatic people and Bedouin tribes, but also for the Underworld. For the most part, the different names and epithets applied to Ha determine definitely his dual nature of hostility and protection: he appeared as a punisher of the foreign Lands and, at the same time, as a powerful protector and a funerary god.
\end{abstract}

Keywords: Ha, Horus, West, Soped, Soker, Oases, Underworld

\section{Introduction ${ }^{*}$}

Being the tutelary god of the $7^{\text {th }}$ nome of Lower Egypt located at the western point of the Delta, his association with the vast Libyan Desert, particularly the regions of the west including the oases, increased as time progressed and he became naturally their principal god. The «Nb Imntt: Lord of the West »was attested as early as the third dynasty where he was firstly mentioned in officials' title «jmj-ht H3: Follower of $\mathrm{Ha} »$. He was the son of the otherwise unknown god Iaaw $^{\dagger}$.The Egyptians had always preferred to represent Ha in a human form, wearing three hills of the hieroglyphic symbol for "desert" or "foreign lands" on his head. The headdress worn by the deity was specific to him; it is a key element for the identification of the god, especially when appearing without inscription

Firstly in 1972, Dieter Wildungwrote a short review about the god Ha entitled "Ha $(H 3)$ " in $L \ddot{A}$ II, col. 923. In 2002, Christian Leitz ${ }^{\star}$ also addressed the goddess Abaset in his valuable lexikon. Five years later and in his illustrated dictionary, L'Egypte ancienne et ses dieux, Jean-Pierre Corteggiani ${ }^{\S}$ wrote a short review on Ha. Finally in 2015, in his paper "Ha in Sheta" Andrzej Ćwiek $^{* *}$ gave more attention to one of Ha's name, namely $H 3-m-\dot{S} t 3$ and he concluded that the coronation cycle in the Portico of the Birth in the temple of Deir el-Bahari includes a scene of purification of Hatshepsut by a god $\mathrm{Ha}$ in Sheta refers to the initiation of the female pharaoh into the secrets of the sun god, enabling her to fulfill her role as the provider of sustenance for humanity.

"I would like to thank Dr. Thomas GAMELIN, University of Lille 3 (France) for reading this article and giving his valuable comments.

${ }^{\dagger}$ See Foster (2001), Ancient Egyptian Literature, p. 240.

${ }^{\dagger}$ See $L G G$ V, p. $10_{\mathrm{B}}-11_{\mathrm{C}}$.

${ }^{8}$ SeeCorteggiani (2007), L'Égypte ancienne et ses dieux, pp. 163-164.

${ }^{* *}$ See Ćwiek(2015), "Ha in Sheta", pp. 83-92. 
The denominations of Ha define his different aspectsas they reveal his nature and personality perceived by the ancient Egyptians. Having a radiant worship for about three thousand years, it seems that the names and qualifiers attributed to the desert-deity witnessed many changes during this long period. They were varied according to the roles played by the god in the Egyptian pantheon. This survey shows the formal and particular names for the god Ha, his titles and his honorary appellations from the Old Kingdom (2647-2150 BC) to the end of the Greco-Roman period (332 BC-642 AD) as well as their developments. Consequently, this study is an attempt to know whether the appellationsof this divinity do vary according to the period? So we have studied the roles he playedthroughout his denominations.

The names and epithets are classified according to the alphabetical hieroglyphic order.The following abbreviations have been used in this study:

\begin{tabular}{|l|l|l|l|}
\hline GF(s) & : Graphical Form(s) & MK & : Middle Kingdom \\
\hline G.-R. & : Greco-Roman Period & NK & : New Kingdom \\
\hline LP & : Late Period & OK & : Old Kingdom \\
\hline
\end{tabular}

\section{Ha'sNames:}

Ha appears under several names according to the various aspects and the evolution of his cult.

II.1- H3: HA

The name of Ha occurs with considerable frequencey in the ancient egyptian texts and the following scripts of his name are collected:

Ha's GFs in the OK*:

เ1
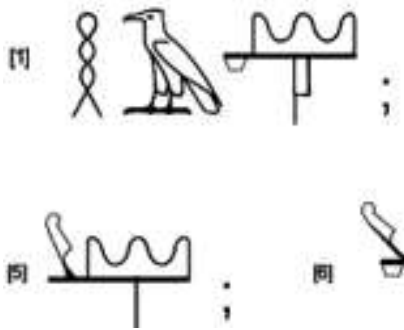
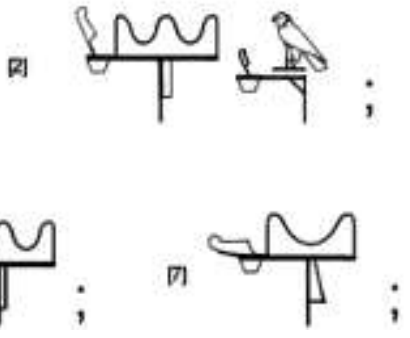

B
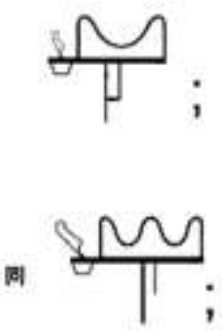

(4)
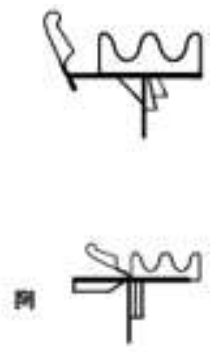

Ha's GFs in the MK ${ }^{\dagger}$

*For the scripts of Ha's name in the OK, see $L G G \mathrm{~V}, 10_{\mathrm{B}}-11_{\mathrm{B}}$ [9]; Faulkner (1969), Pyramid Texts, p. 253; Sethe (1960), Pyramidentexte, Utterance 610 (Pyr. § 1712b):[=GF n $\left.{ }^{\circ} 1-2\right]$; Allen, (2005), Pyramid Texts, p. 29; Faulkner (1969), Pyramid Texts, p. 37; Sethe (1960), Pyramidentexte, Utterance 204 (Pyr. §119b: [=GF $\left.{ }^{\circ} 3\right] ; L G G$ V, $10_{\mathrm{B}^{-}}$

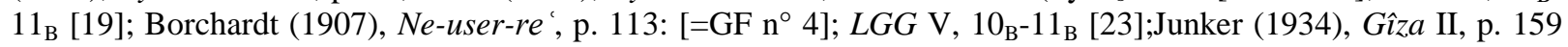
$\left(\mathrm{n}^{\circ}\right.$ 17): [=GF ${ }^{\circ}$ 5]; $L G G \mathrm{~V}, 10_{\mathrm{B}}-11_{\mathrm{B}}$ [24]; Lepsius (1849), Denkmäler II, pp. 27 and 29: [=GF ${ }^{\circ}$ 6]; $L G G$ V, 10 $\mathrm{B}^{-}$ 11 $1_{\mathrm{B}}$ [25]; Mariette (1889), Les mastabas, p. 228, 230 (D19) : [=GF n 7];LGG V, 10 B $^{\circ} 11_{\mathrm{B}}$ [26]; Mariette (1889), Les mastabas, pp. 228, 230 and p. 400 (E8) [=GF n 8];LGG V, 10 B $^{\circ} 11_{\mathrm{B}}$ [33]; Ziegler, (1999), L'artégyptien, p.

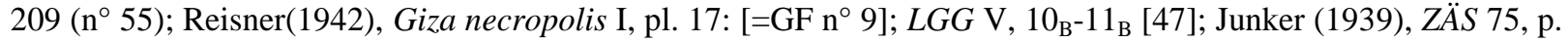
$70\left(\mathrm{n}^{\circ} 34\right):\left[=\mathrm{GF} \mathrm{n} \mathrm{n}^{\circ} 4\right]$.

${ }^{\dagger}$ For the GFs of Ha's name in the MK, see $L G G \mathrm{~V}, 10_{\mathrm{B}}-11_{\mathrm{A}}$ [1]; Faulkner (1973), Coffin Texts I, p. 25; Buck (1935), Coffin Texts I, spell 36 (139c) [=GF n $\left.{ }^{\circ} 10-14\right]$; LGG V, 10 ${ }_{\mathrm{B}}-11_{\mathrm{A}}$ [2]; Faulkner (1973), Coffin Texts I, p. 140; Buck (1935), Coffin Texts II, spell 162 (395c) [=GF n $\left.{ }^{\circ} 15-21\right] ; L G G \mathrm{~V}, 10_{\mathrm{B}}-11_{\mathrm{A}}$ [3]; Faulkner (1977), Coffin Texts II, p. 121; Buck (1935), Coffin Texts VI, spell 479 (38aa) [=GF n 22]; LGG V, 10 B $^{\circ} 11_{\mathrm{A}}$ [4]; Faulkner (1977), Coffin Texts II, p. 207; Buck (1935), Coffin Texts VI, spell 624 (240p) [=GF n ${ }^{\circ}$ 23]; LGG V, 10 B $^{-11_{\mathrm{A}}}$ [5]; Faulkner (1977), Coffin Texts II, p. 288; Buck (1935), Coffin Texts VI, spell 755 (384o) [=GF n $\left.{ }^{\circ} 24\right] ; L G G$ V, 10 $\mathrm{B}_{\mathrm{B}}-11_{\mathrm{A}}$ [6]; Faulkner (1977), Coffin Texts II, p. 289; Buck (1935), Coffin Texts VI, spell 756 (386a) [=GF n $\left.{ }^{\circ} 25\right]^{;} L_{G G} \mathrm{~V}, 10_{\mathrm{B}^{-}}$ 


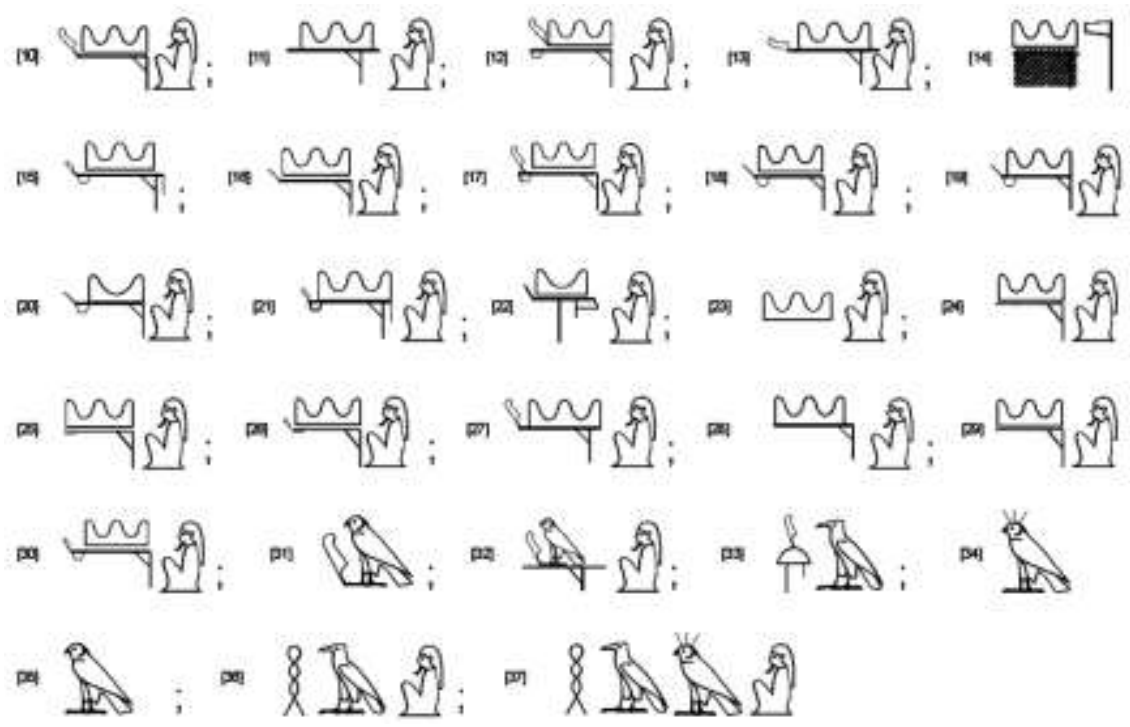

Ha's GFs in the $\mathrm{NK}^{*}$

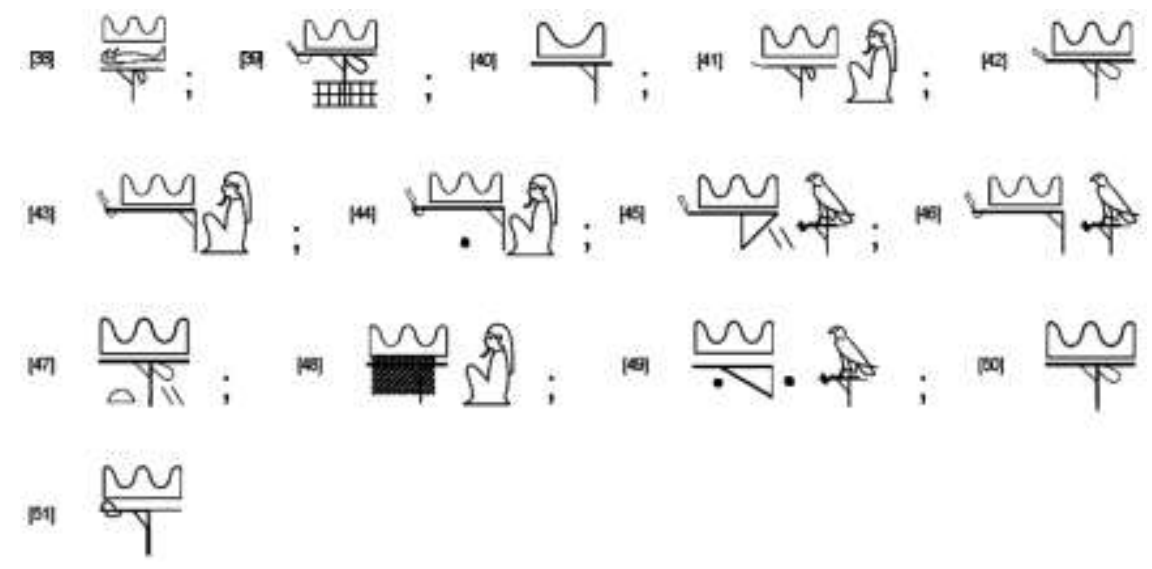

Ha's GFs in the $\mathrm{LP}^{\dagger}$

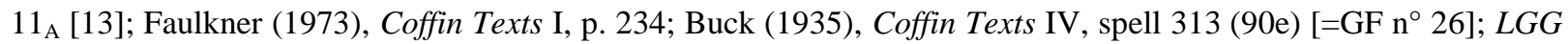

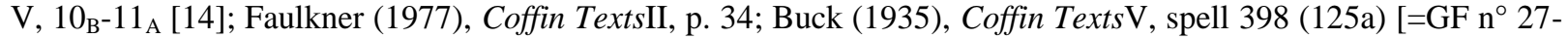
30]; $L G G \mathrm{~V}, 10_{\mathrm{B}}-11_{\mathrm{B}}$ [31]; Brunner-Traut and Brunner (1981), Die ÄgyptischeSammlungI, p. 211 and II, pl. 40 [=GF n ${ }^{\circ} 31$ ]; $L G G \mathrm{~V}, 10_{\mathrm{B}}-11_{\mathrm{B}}$ [42]; Chassinat and Palanque (1911), Unecampagne de fouilles, $\mathrm{p} .16$ [=GF $\mathrm{n}^{\circ} 32-$ 35]; $L G G \mathrm{~V}, 10_{\mathrm{B}}-11_{\mathrm{B}}$ [42]; Gauthier (1923), $A S A E 23$, p. 5 [=GF n ${ }^{\circ} 36$ ]; $L G G \mathrm{~V}, 10_{\mathrm{B}}-11_{\mathrm{B}}$ [45]; Chassinat and Palanque (1911), Unecampagne de fouilles, p. 16 [=GF n $\left.{ }^{\circ} 18-21\right]$; $L G G \mathrm{~V}, 10_{\mathrm{B}}-11_{\mathrm{B}}$ [48]; Kamal (1913-1914), $A S A E$ 16, p. 71, 76. [=GF n ${ }^{\circ}$ 36-37].

"For the GFs of Ha's name in the NK, see $L G G \mathrm{~V}, 10_{\mathrm{B}}-11_{\mathrm{A}}$ [11]; Piankoff (1942), Le livre du jour et de la nuit, p. 27 [=GF n ${ }^{\circ} 38$ ]; $L G G$ V, 10 ${ }_{\mathrm{B}}-11_{\mathrm{A}}$ [12]; Naville (1901), Deir El BahariIV, pl. 110 [=GF n 39]; LGG V, 10 ${ }_{\mathrm{B}}-11_{\mathrm{B}}$ [15]; Helck (1957), UrkundenIV, 1555, 16 [=GF n $\left.{ }^{\circ} 40\right]$; $L G G \mathrm{~V}, 10_{\mathrm{B}}-11_{\mathrm{B}}$ [17]; Seele (1959), The Tomb of Tjanefer, pl. 31 [=GF ${ }^{\circ}$ 41]; Kitchen (2014), Ramesside Inscriptions VII, p. 17; LGG V, 10 $\mathrm{B}_{\mathrm{B}}-11_{\mathrm{B}}$ [27]; KRI VII, 23, 4 [=GF $\mathrm{n}^{\circ}$ 42]; $L G G \mathrm{~V}, 10_{\mathrm{B}}-11_{\mathrm{B}}$ [28]; Monnet, (1951) $R d E ́$ 8, 159-160 [=GF n $\left.{ }^{\circ} 43-46\right]$; $L G G \mathrm{~V}, 10_{\mathrm{B}}-11_{\mathrm{B}}$ [29]; KoefoedPetersen (1951), Catalogue des sarcophages, p. 17, pl. 25 [=GF n $\left.{ }^{\circ} 47\right]$; $L G G$ V, 10 B $^{-11_{\mathrm{B}}}$ [34]; Davies (1923),

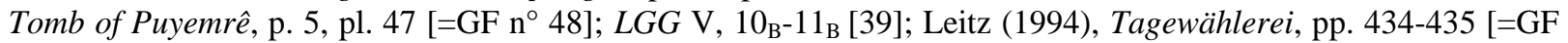
$\mathrm{n}^{\circ} 49$ ]; $L G G \mathrm{~V}, 10_{\mathrm{B}}-11_{\mathrm{B}}$ [41]; Junge (1987), Elephantine XI, p. 19 (n 3.1.6.1) [=GF n ${ }^{\circ} 50$ ]; $L G G \mathrm{~V}, 10_{\mathrm{B}}-11_{\mathrm{B}}$ [53]; Thiem (2000), Gebel es-Silsileh, p. 207, 334 [=GF n ${ }^{\circ}$ 51].

'For the GFs of Ha's name in the LP, see $L G G \mathrm{~V}, 10_{\mathrm{B}}-11_{\mathrm{B}}$ [16]; Vercoutter (1962), Sérapéum de Memphis, p. 65, pl. 9 [=GF n ${ }^{\circ} 52$ ]; $L G G \mathrm{~V}, 10_{\mathrm{B}}-11_{\mathrm{B}}$ [18]; Bresciani (1983), Saqqara I, p. 57, pl. 11[=GF n ${ }^{\circ} 53$ ]; $L G G \mathrm{~V}, 10_{\mathrm{B}}-11_{\mathrm{B}}$ [20]; 
International Journal of Heritage, Tourism and Hospitality Vol. (13), No. (1), March, 2019 By: Faculty of Tourism and Hotels, Fayoum University

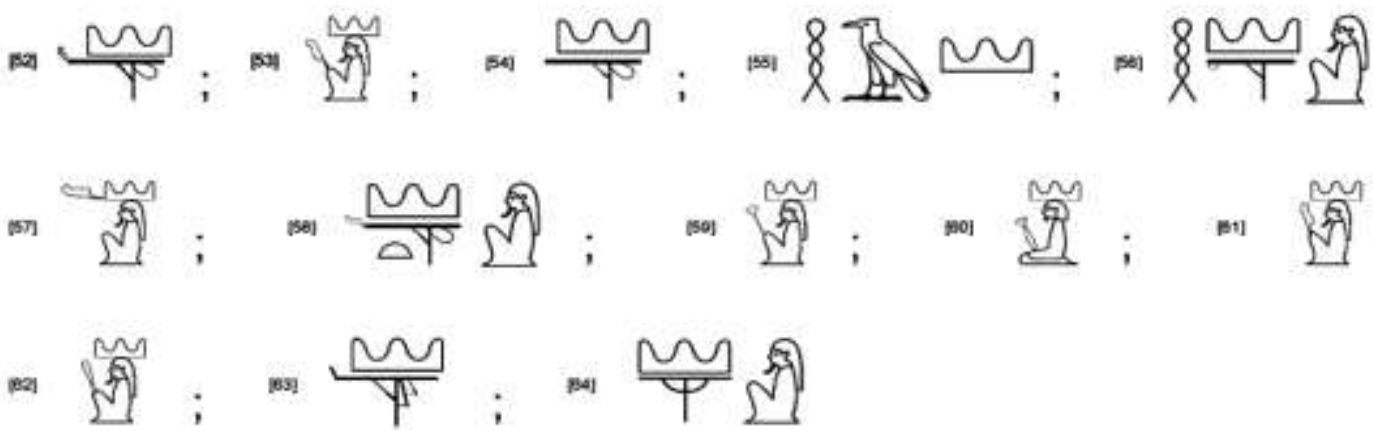

Ha's GFs in the G.-R. :

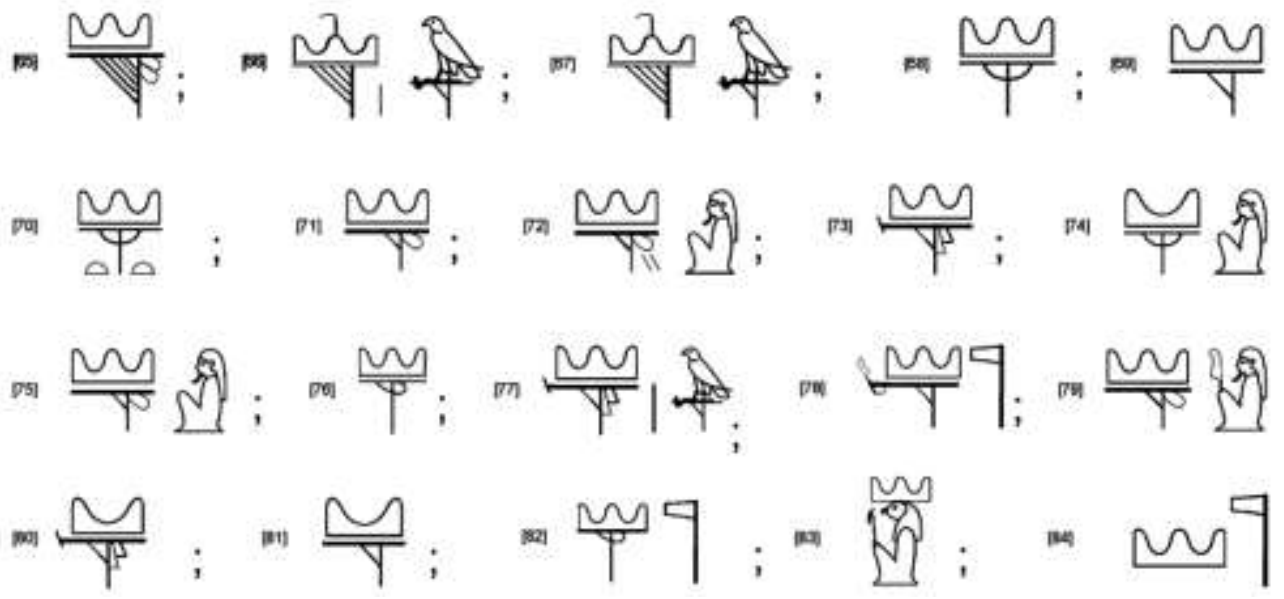

Fakhry (1942), Bahria Oasis I, p. 88, pl. 34B [=GF n ${ }^{\circ}$ 54]; LGG V, 10 ${ }_{\mathrm{B}}-11_{\mathrm{B}}$ [21]; Fakhry (1942), Bahria Oasis I, p. 158, pl. 51A [=GF n $\left.{ }^{\circ} 55\right]$; $L G G \mathrm{~V}, 10_{\mathrm{B}}-11_{\mathrm{B}}$ [30]; Davies (1953), The Temple of Hibis, p. 19, pl. 18 (west wall): [=GF n $\left.{ }^{\circ} 56\right] ; L G G \mathrm{~V}, 10_{\mathrm{B}}-11_{\mathrm{B}}$ [37]; Perdu (1994), Musée de Picardie, pp. 112-113 [=GF n ${ }^{\circ} 57$ ]; $L G G \mathrm{~V}, 10_{\mathrm{B}}-11_{\mathrm{B}}$ [40]; Naville (1892), The Festival-Hall of Osorkon II, pl. 12, 7 [=GF $\mathrm{n}^{\circ}$ 58]; $L G G$ V, $10_{\mathrm{B}}-11_{\mathrm{B}}$ [43]; Wildung (1969), Die Rolle ägyptischerKönige, p. 79, 80, pl. 7, 8 (n $\left.{ }^{\circ}\right)$ [=GF $\mathrm{n}^{\circ}$ 59-61]; $L G G \mathrm{~V}, 10_{\mathrm{B}}-11_{\mathrm{B}}$ [49]; Chassinat (1899), RecTrav XXI, p. 67 [=GF n ${ }^{\circ}$ 62]; $L G G$ V, 10 ${ }_{\mathrm{B}}-11_{\mathrm{B}}$ [49]; Chassinat (1900), RecTrav XXII, p. 179 [=GF n ${ }^{\circ}$ 63]; $L G G \mathrm{~V}, 10_{\mathrm{B}}-11_{\mathrm{B}}$ [68]; Josephson (1999), Statues of the XXVth and XXVI $I^{\text {th }}$ Dynasties, p. 75 [=GF ${ }^{\circ}$ 64].

"For the GFs of Ha's name in the G.-R., see $L G G$ V, $10_{\mathrm{B}}-11_{\mathrm{A}}$ [7]; Beinlich (1991), Das BuchvomFayum, pp. 481-

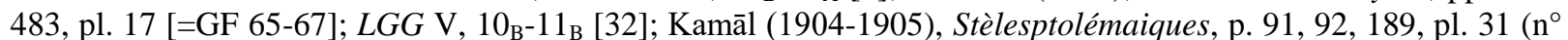
CG 22104), pl. 32 ( $\left.{ }^{\circ} \mathrm{CG} 22105\right), \mathrm{CG} 22191$, [=GF 68-71]; LGG V, 10 ${ }_{\mathrm{B}}-11_{\mathrm{B}}$ [44]; Goyon (1975), BIFAO 75, p. 388, 389 [=GF 72]; $L G G \mathrm{~V}, 10_{\mathrm{B}}-11_{\mathrm{B}}$ [50]; Spiegelberg (1906-1908), Die demotischenDenkmälerm, p. $274\left(\mathrm{n}^{\circ} 25\right)$ [=GF 73]; $L G G \mathrm{~V}, 10_{\mathrm{B}}-11_{\mathrm{B}}$ [51]; Rochemonteix (1984), Le temple d'Edfou I, 1, p. 53 (n ${ }^{\circ}$ 52) [=GF 75]; $L G G \mathrm{~V}$, $10_{\mathrm{B}}-11_{\mathrm{B}}$ [52]; Junker (1958), Tempels der Isis in Philä, p. 16, pl. 8 [=GF 74]; $L G G \mathrm{~V}, 10_{\mathrm{B}}-11_{\mathrm{B}}$ [54]; Chassinat (1933), Le temple d'Edfou VIII, 77, 3; Kurth (1998), Edfou VIII, p. 138 [=GF 75]; LGG V, 10 ${ }_{\mathrm{B}}-11_{\mathrm{B}}$ [55]; Rochemonteix (1987), Le temple d'Edfou I, 3, p. 331, 16 [=GF 73]; LGG V, 10 B $11_{\mathrm{B}}$ [56]; Daumas (1959), Les Mammisis de Dendara, p. 141 ( ${ }^{\circ}$ 24) [=GF 76]; LGG V, 10 ${ }_{\mathrm{B}}-11_{\mathrm{C}}$ [57]; Cauville (2004), Dendara V-VI, p. 112, 113; Chassinat (1947), Le Temple de Dendara V, p. 30, 9 [=GF 76]; $L G G \mathrm{~V}, 10_{\mathrm{B}}-11_{\mathrm{C}}$ [58]; Chassinat (1987), Le

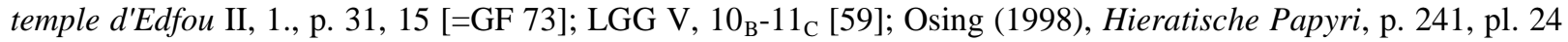

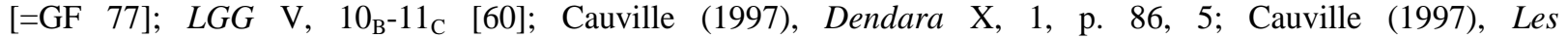
chapellesosiriennes, p. 48 (86) [=GF 78]; LGG V, 10 B $1_{\mathrm{C}}$ [61]; Morgan (1895), KomOmbos I, 282, E [=GF 79]; $L G G \mathrm{~V}, 10_{\mathrm{B}}-11_{\mathrm{C}}$ [62]; Chassinat (1990), Le Temple d'Edfou II, 2, p. 289, 2 [=GF 80]; LGG V, 10 ${ }_{\mathrm{B}}-11_{\mathrm{C}}$ [63]; Chassinat (1928), Le temple d'Edfou III, p. 107, 5 [=GF 74]; ]; LGG V, 10 10-11 [64]; Chassinat (1928), Le temple d'Edfou III, p. 226, 14, pl. 73 [=GF 81]; LGG V, 10 B $11_{\mathrm{C}}$ [65]; Chassinat (1928), Le temple d'Edfou III, p. 342, 7

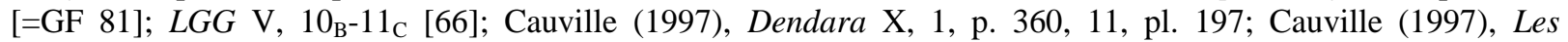

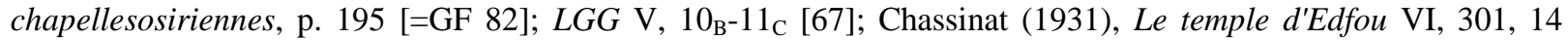

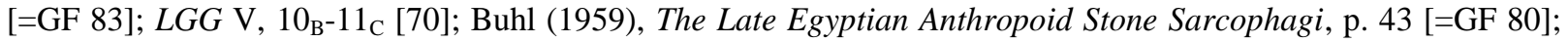
$L G G \mathrm{~V}, 10_{\mathrm{B}}-11_{\mathrm{C}}$ [71]; Buhl (1959), The Late Egyptian Anthropoid Stone Sarcophagi, p. 103 [=GF 84]. 
$H 3$ is the formal and most common name for the god Ha. Its earliest occurrence is being part of official's title «jmj-ht H3: Follower of the god Ha ». His name was written with the hieroglyphic sign representing a landscape feature of a triple mountain $\mathrm{N}$ [N25], sometimes a mountain with two points $\bigcirc$ [N26), placed on a standard "Y [R12], to which can be added an ostrich feather is [H6] that one finds in Imentet's name. The hieroglyph $\sim$ stands for h3st: "mountain", "desert", "foreign country". Ha's names end usually with the determinative of masculine divinities [A40], but very rarly they terminate with the determinative of cloth wound on a pole"l[R8] or without any determinative.

\section{II.2.H3-Imn-Wn-nfr: HA-Amon-Wen-nofre}

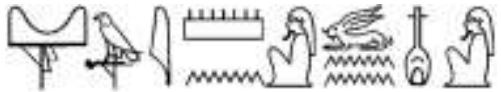

This seemingly hapaxname is not identified by Leitz. It occurs only once in a written record in connection with Ha. It is writtenin the south wall of the burial chamber of the treasurer Sobkmosě from Er Rizeikāt ${ }^{\dagger}$ : HA-Amon-Wen-nofre is entitled «Hry-tp $m 3^{`} t$ : Master of right ». Hayes ${ }^{*}$ translates this name as HA, Amon and Wen-nofre, but the singular suffix pronoun of the second person coming after deity's name refers to a singular composite divine form.

\section{II.3.H3 9: Ha-the-Great}

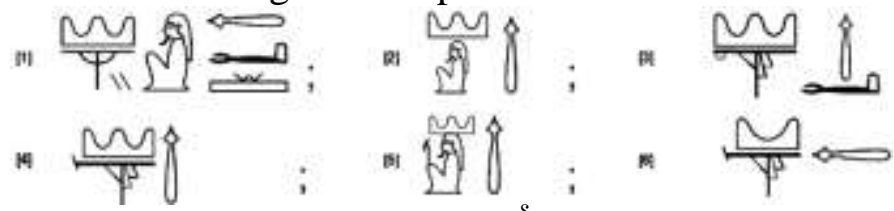

Ha-the-Great is collected by Christian Leitz in his valuable lexikon ${ }^{\S}$. This name wasn't known before the NK and more precisely in the inscriptions of the tomb $\mathrm{n}^{\circ} 192$ in the Theban necropolis $^{* *} . H_{3}$ '3's legend was unfortunately damaged and his epithets disappeared ${ }^{\dagger \dagger}$. In the LP, his only known $\mathrm{GF}^{+1}$ was followed by his standard title: «Nb Imntt: Lord of the West ».

In the G.-R., the $\mathrm{GF}^{\S \S}$ of this compound name are much more inscribed on the walls of the temples. $H_{3}$ (3) is described as: «ntr 93: Great god», Hry-ib Iwnt: He who resides in Iounet », « $H w$ h 3 swt: He who strikes the foreign Lands », "Ptpt Mntyw: He who destroys the Mntyw-tribe

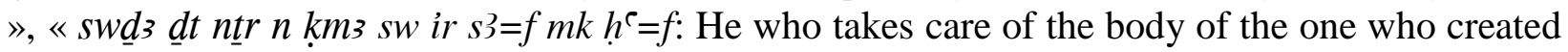
him, makes his protection and protects his body », «ntr mnh: Potent god», «irnht $n i t=f d r \underline{d w} n b$

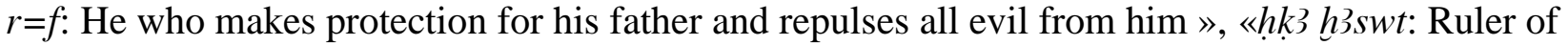

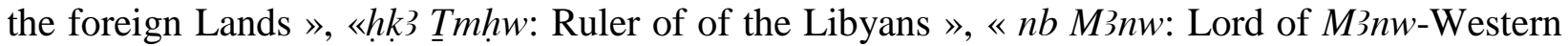
Mountain » and «hk ${ }^{\complement} h h^{\complement} t$ wrt: Ruler of Great necropolis ».

\footnotetext{
"SeeWildung, (1972), MiscellaneaWilbouriana I, pp. 157-159.

${ }^{\dagger}$ See Hayes (1939), The burial chamber of the treasurer Sobk-mosĕ, p. 19 and pl. 5.

* See Hayes (1939), The burial chamber of the treasurer Sobk-moseе, p. 19.

${ }^{\S}$ See $L G G \mathrm{~V}, 11_{\mathrm{C}}[1-7]$

** This tomb is the largest private tomb known from the $18^{\text {th }}$ Dynasty and was intended to be the final resting place for Kheruef, the royal scribe and steward to Amenhotep III's principal wife, Queen Tiye, but the tomb was abandoned before completion and Kheruef was apparently buried elsewhere.

${ }^{\dagger}$ For the GFs of $1 \mathrm{~A}$ aA in the OK see $L G G \mathrm{~V}, 11_{\mathrm{C}}$ [3]; The Epigraphic survey (1980), The tomb of Kheruef, pl. 21, 4: [=GF 3].

\#See $L G G$ V, 11 [1]; Schott (1929), UrkundenVI, 33, 4: [=GF 1].

${ }^{\S \S}$ For the GFs of $1 \mathrm{~A}$ aA in the G.-R., seeLGG V, 11, [2]; Brugsch (1891), altägyptischerDenkmäler, p. 1576: [=GF 2]; LGG V, 11, [5]; Cauville (2000), Dendara III: Traduction, pp. 70-71; Chassinat (1935), le Temple de DendaraIII, p. 27, 9, pl. 172: [=GF 6]; LGG V, 11 C [5]; Chassinat (1990), Le Temple d'EdfouII, 2, 289, 6, pl. 45c: [=GF 6].
} 


\section{II.4.H3-m-S $t 3$ : Ha in Sheta}

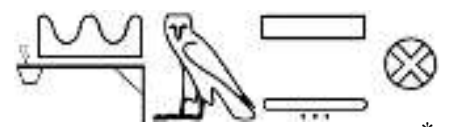

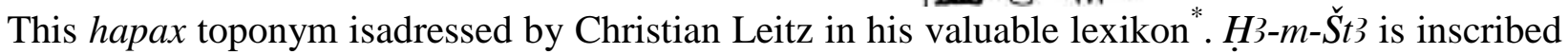
in the temple of Hatshepsut at Deir-el-Bahari, precisely on the last but one scene on the west wall of the upper register of the walls of the Portico of the Birth. This name consists of threes words: Ha's name, a prepeosition and a place name. Andrzej Ćwiek analyzed separately the three signs constructing the place name and he concluded that the general idea of secret, mystery, hiding is involved in this word. the determinative of town might suggest that it is the city of secrets. One might translate this name as: "Ha is in the palce of secrets".No epithet is attributed to Ha in Sheta.

\section{II.5.H3-Spd:Ha-Soped}

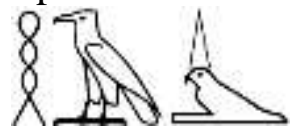

This composite name occurs only once ina written record in relation with the desert-deity. HaSoped was mentionned only in the the MK $\mathrm{MK}^{\dagger}$ H-Spd can be followed by the standard title of Ha: «b Imntt: Lord of the West ».

\section{II.6.H3-Skr: Ha-Soker}

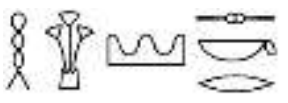

The only occurance of this composite name is attested in the G-R. + . This hapax name is entitled « $n b$ 3ht: Lord of horizon ».

\section{II.7. $H r-H 3^{\S}$ : Horus-HA}

(10)

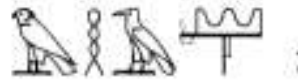

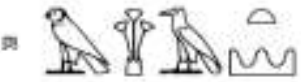

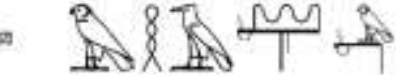

An

The occurrence of this compound name was well known from a very early period as he was mentioned in the oldest known corpus of the Pyramid Texts dating to the OK. Hr-H3's name was written in the religious texts which were found in each of the pyramids of Pepi I, Merenre I and Pepi II ${ }^{* *}$.

In the $\mathrm{MK}^{\dagger \dagger}, H r-H 3$ was called $\ll s 3$ nd $i t=f$ : the son who protects his father ${ }^{*}$. In the LP, the only known drawing of this composite divine form was carved in the North Reveal of the entrance doorway of the Sanctuary $(\mathrm{A})^{\S \S}$. Horus-Ha appears as a Male figure wearing his distinctive headdress of the foreign land sign. His right hand is gripping a knife, while his left one is holding a bow. He drags a captive in each hand (=Fig. 1)

\footnotetext{
"See $L G G \mathrm{~V}, 11_{\mathrm{C}}[1]$.

${ }^{\dagger}$ This name is not identified by Leitz. For the GF of this name, see Gauthier (1923), ASAE 23, p. 19.

${ }^{\sharp}$ See $L G G \mathrm{~V}, 10_{\mathrm{B}}-11_{\mathrm{A}}$ [8]; Maspero (1908), Sarcophages, p. 55.

${ }^{\S}$ For the GFs of 1r-1A, see $L G G$ V, 272 C [2]; Faulkner (1969), Pyramid Texts, p. 170; Sethe (1960), Pyramidentexte, Utterance 483 (Pyr. § 1013d):[=GF n $\left.{ }^{\circ} 1-2\right] ; L G G$ V, 272 ${ }_{\mathrm{C}}$ [1]; Faulkner (1977), Coffin Texts II, p. 58; Buck (1961),The Egyptian Coffin Texts VII, 111d (Utterance 483): [=GF n ${ }^{\circ}$ 3];LGG V, 272 $\mathrm{C}$ [3]; Davies (1953), The Temple of Hibis, p. 19, pl. 5, 4 (North Reveal): [=GF n $\left.{ }^{\circ} 4\right]$.

*** See LGG V, 272C [2]; Faulkner (1969), Pyramid Texts, p. 170; Sethe (1960), Pyramidentexte, Utterance 483 (Pyr. $\S 1013 \mathrm{~d}):\left[=\mathrm{GF} \mathrm{n}{ }^{\circ} 1-2\right]$.

${ }^{\dagger} L G G$ V, 272 [1]; Faulkner (1977), Coffin Texts II, p. 58; Buck (1961), The Egyptian Coffin Texts VII, 111d (Utterance 483): [=GF $\mathrm{n}^{\circ}$ 3].

$\$$ For this appellation see infra, epithet $\mathrm{n}^{\circ} 36$.

${ }^{\S \S}$ See $L G G$ V, 272 $\mathrm{C}$ [3]; Davies (1953), The Temple of Hibis, p. 19, pl. 5, 4 (North Reveal): [=GF n ${ }^{\circ}$ ]]
} 
Figure 1: the god Horus-Ha

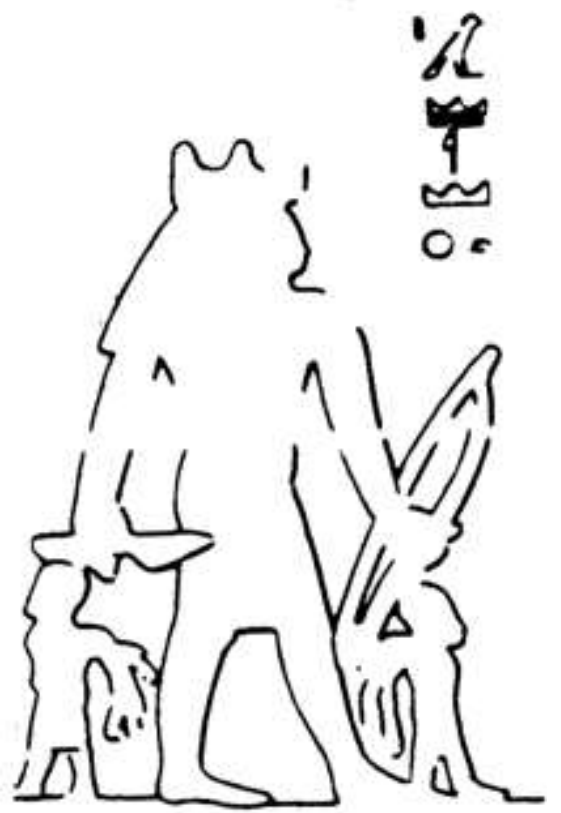

After: Davies, (1953), The Temple of Hibis, pl. 5, 4 (North Reveal).

\section{II.8.Sbsw-H3: Sebsebu-Ha*}

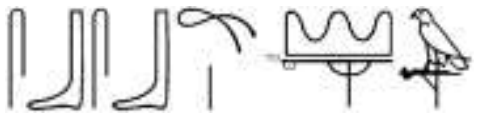

In the late texts,Ha is occasionally called "Sbsw-H3: Sebsebu-Ha" in a magical context. Neither title nor honorific appellation followed this name of Ha.

III. God's Ha Epithets:

\begin{tabular}{|c|c|c|c|}
\hline \multirow{2}{*}{$\mathrm{N}^{\mathrm{o}}$} & \multirow{2}{*}{ Epithet } & \multirow{2}{*}{ Grapgical form(s) } & Dating \\
\hline & & & Ha's name(s) \\
\hline \multirow{2}{*}{ (1) } & \multirow{2}{*}{$\begin{array}{l}\text { "Imy dw3t: He who is in the } \\
\text { netherworld }{ }^{\dagger}\end{array}$} & \multirow{2}{*}{ 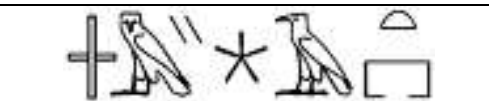 } & NK \\
\hline & & & $H 3$ \\
\hline (2) & $\begin{array}{l}\text { «ir nht } n i t=f d r d w n b r=f: \text { He who } \\
\text { makes protection for his father and } \\
\text { repulses all evil from him } »^{\dagger}\end{array}$ & 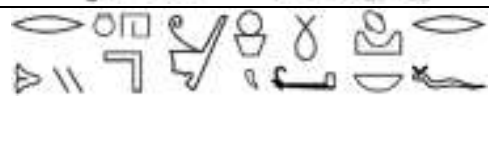 & $\mathrm{H}_{3} \mathrm{e}$ \\
\hline \multirow[b]{2}{*}{ (3) } & \multirow{2}{*}{$\begin{array}{l}\text { « } i r \quad n h w n S r-h d t: \text { He who makes } \\
\text { effective protection for the Prince of the } \\
\text { White Crown(= Osiris)» } \S\end{array}$} & \multirow{2}{*}{ 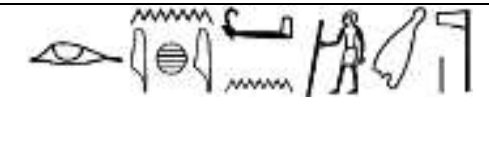 } & G.-R. \\
\hline & & & $H 3$ \\
\hline (4) & «Iry ${ }^{C} h \tau^{*} \underline{d}$ dsrt: Guardian of the sacred & $\overbrace{0}$ & NK \\
\hline
\end{tabular}

"See $L G G$ II, 829A ; Verhoeven(1993), Das saitischeTotenbuchI (Text), p. 239 (Utterance 125, 56, 24) and II (Hieroglyphic Transcription), p. 84* (Utterance 125, 56, 24).

${ }^{\dagger}$ See Le Page Renouf and Naville (1904), The Egyptian Book of the Dead, p. 91, pl. 14.

${ }^{\ddagger}$ See $L G G$ V, 11 1 [5]; Cauville (2000), Dendara III: Traduction, pp. 70-71; Chassinat (1935), le Temple de DendaraIII, p. 27, 10, pl. 172.

${ }^{\S}$ See $L G G \mathrm{~V}, 10_{\mathrm{B}}-11_{\mathrm{C}}$ [57]; Cauville (2004), DendaraV-VI, p. 112, 113;Chassinat (1947), Le Temple de DendaraV, p. 30,9 . 
International Journal of Heritage, Tourism and Hospitality Vol. (13), No. (1), March, 2019 By: Faculty of Tourism and Hotels, Fayoum University

\begin{tabular}{|c|c|c|c|}
\hline & necropolis $»^{\dagger}$ & & $H 3$ \\
\hline \multirow{2}{*}{ (5) } & \multirow{2}{*}{ «? phty: Great of might $»^{+}$} & & G.-R. \\
\hline & & & $H 3$ \\
\hline \multirow{2}{*}{ (6) } & \multirow{2}{*}{ «rk-ins: He who binds the red strip» ${ }^{\S}$} & & LP \\
\hline & & & $H 3$ \\
\hline \multirow{2}{*}{ (7) } & \multirow{2}{*}{ «wr šfyt: Great of terror» ${ }^{* *}$} & & G.-R. \\
\hline & & & $H 3$ \\
\hline \multirow{2}{*}{ (8) } & \multirow{2}{*}{$\begin{array}{l}\text { «wdi-r-s } r k m \text { Fnhw } w^{\dagger}: \text { He who puts an } \\
\text { end to Asiatic people } »\end{array}$} & $y^{\circ} \Leftrightarrow \stackrel{\infty}{\leftrightarrows} \gamma^{2}$, vi! & G.-R. \\
\hline & & $\triangle 100 \mathrm{MLi}$ & $H 3$ \\
\hline \multirow{2}{*}{ (9) } & \multirow{2}{*}{$\begin{array}{l}\text { «Ptpt Mntyw } w^{\$ \S}: \text { He who destroys the } \\
M n t y w \text {-tribe » }\end{array}$} & بس & G.-R. \\
\hline & & $\frown \curvearrowleft$ & $H 33$ \\
\hline \multirow{2}{*}{ (10) } & \multirow{2}{*}{$\ll N b 3 h t$ : Lord of Horizon $»^{\dagger \dagger}$} & & G.-R. \\
\hline & & & $H 3-S k r$ \\
\hline (11) & «b Imntt: Lord of the West ${ }^{+t} »$ & & \\
\hline \multirow{2}{*}{ (1) } & $B 0$ & $\cap$ & $\mathrm{MK}^{\S \S \S}$ \\
\hline & $\longrightarrow \int_{1}^{0} ; \quad$ a & Rि & $\begin{array}{c}H 3 \\
H 3-S p d\end{array}$ \\
\hline
\end{tabular}

" aHat is a euphemism frequently used to designate the tomb or the region of the tombs, the necropolis, see $\mathrm{H}$. Gauthier (1925), Dictionnaire des nomsgéographiques I, p. 156.

${ }^{\dagger}$ See $L G G \mathrm{~V}, 10_{\mathrm{B}}-11_{\mathrm{B}}$ [17]; Seele (1959), The Tomb of Tjanefer, pl. 31.

${ }^{+}$See $L G G \mathrm{~V}, 10_{\mathrm{B}}-11_{\mathrm{C}}$ [60]; Cauville (1997), Dendara X, 1, p. 86, 5; Cauville (1997), Les chapelles osiriennes, p. 48 (86).

${ }^{\S}$ See $L G G \mathrm{~V}, 10_{\mathrm{B}}-11_{\mathrm{B}}$ [18]; Bresciani (1983), Saqqara I, p. 57, pl. 11; $L G G \mathrm{~V}, 10_{\mathrm{B}}-11_{\mathrm{B}}$ [49]; Chassinat (1900), RecTrav XXII, p. 179.

${ }^{* *}$ See $L G G \mathrm{~V}, 10_{\mathrm{B}}-11_{\mathrm{C}}$ [60]; Cauville (1997), Dendara X, 1, p. 86, 5; Cauville (1997), Les chapelles osiriennes, p. 48 (86).

"Fnxw, which is a common name meaning "the attached, the captives", was applied in a general way to all foreign populations of ancient Asia, See Gauthier (1925), Dictionnaire des nomsgéographiques II, p. 161.

"See $L G G \mathrm{~V}, 10_{\mathrm{B}}-11_{\mathrm{B}}$ [52]; Junker (1958), Tempels der Isis in Philä, p. 16, pl. 8.

${ }^{\S \S}$ MnTywis a tribe of the Libyan Desert,living on the Nile water in its eastern part and rainwater in its western part. Its permanent residentwas located in the zone of the Libyan desert which extends to the west of the first cataract of the Nile, see Gauthier (1926), Dictionnaire des nomsgéographiques III, p. 43.

${ }^{* * *}$ See $L G G \mathrm{~V}, 11_{\mathrm{C}}$ [5]; Cauville (2000), Dendara III: Traduction, pp. 70-71; Chassinat (1935), le Temple de DendaraIII, p. 27, 9, pl. 172.

${ }^{\dagger}$ See $L G G \mathrm{~V}, 10_{\mathrm{B}}-11_{\mathrm{A}}$ [8]; Maspero (1908), Sarcophages, p. 55.

${ }^{+1}$ The Ancient Egyptians were exceedingly fond of puns, believing that homophony in language was no meaningless coincidence. They crop up frequently in both religious and informal contexts. in our case, the word Imntt stands not only for the western desert and its oases, but also the land of the hidden ones (underworld).

${ }^{\S \S \S}$ For the GFs of this title in the MK, see $L G G$ V, $10_{\mathrm{B}}-11_{\mathrm{A}}$ [13]; Faulkner (1973), Coffin Texts I, p. 234; Buck (1935), Coffin Texts IV, spell 313 (90e) [=GF n ${ }^{\circ}$ ] ; LGG V, 10 ${ }_{\mathrm{B}}-11_{\mathrm{A}}$ [14]; Faulkner (1977), Coffin Texts II, p. 34; Buck (1935), Coffin Texts V, spell 398 (125a) [=GF n ${ }^{\circ} 1-3$ ]; $L G G \mathrm{~V}, 10_{\mathrm{B}}-11_{\mathrm{B}}$ [31]; Brunner-Traut and Brunner (1981), Die ÄgyptischeSammlungI, p. 211 and II, pl. 40 [=GF n ${ }^{\circ}$ 4]; $L G G \mathrm{~V}, 10_{\mathrm{B}}-11_{\mathrm{B}}$ [42]; Chassinat and Palanque (1911), Unecampagne de fouilles, p. 16 [=GF n $\left.{ }^{\circ} 1,3,4,5\right] ; L G G \mathrm{~V}, 10_{\mathrm{B}}-11_{\mathrm{B}}$ [45-46]; Gauthier (1923), ASAE 23, p. 5, 19 [=GF n ${ }^{\circ}$ 1]; $L G G \mathrm{~V}, 10_{\mathrm{B}}-11_{\mathrm{B}}$ [48]; Kamal (1913-1914), ASAE 16, p. 71, 76 [=GF n 6]. 
International Journal of Heritage, Tourism and Hospitality Vol. (13), No. (1), March, 2019 By: Faculty of Tourism and Hotels, Fayoum University

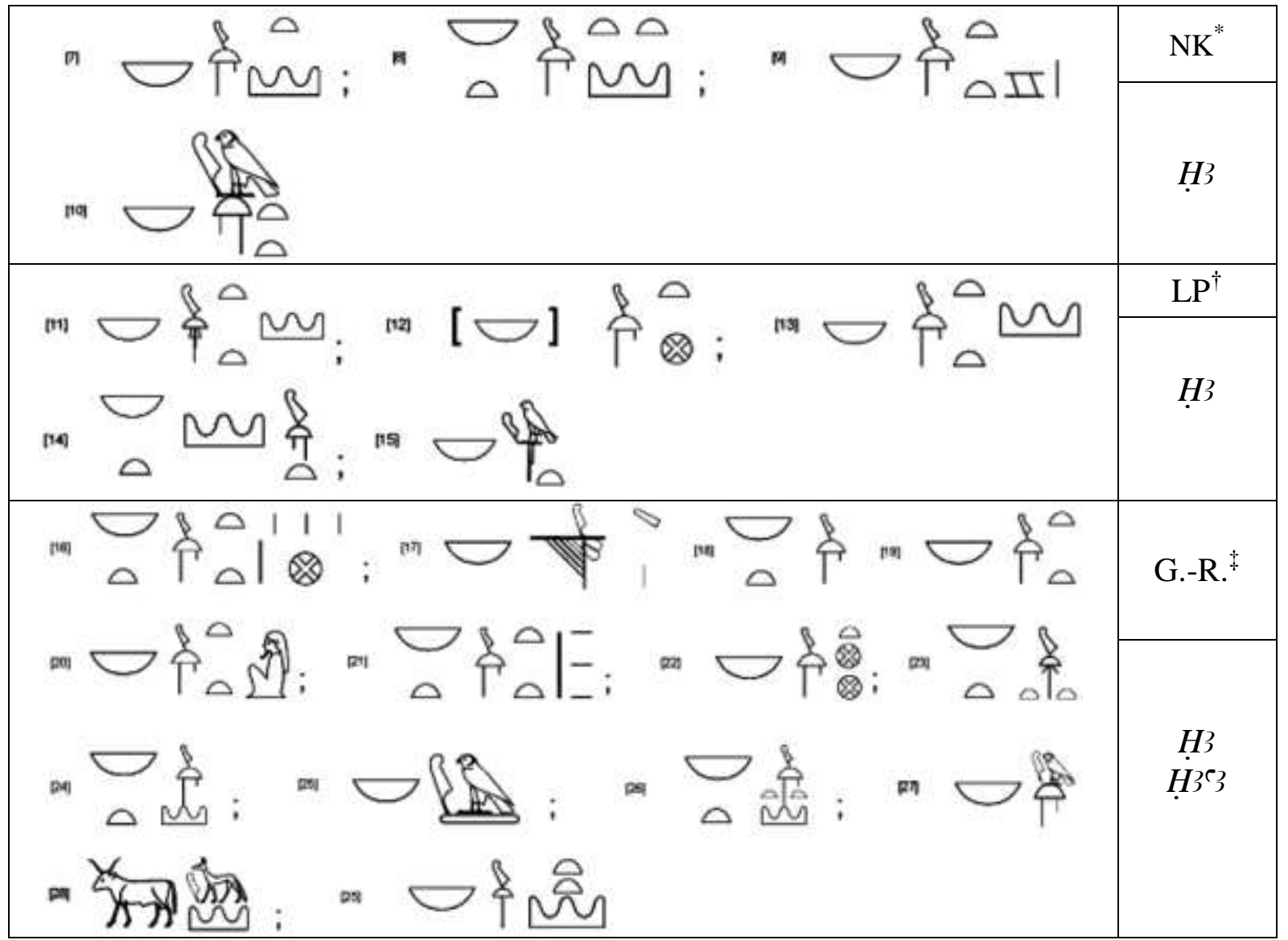

"For the GFs of this title in the NK, $L G G \mathrm{~V}, 10_{\mathrm{B}}-11_{\mathrm{B}}$ [15]; Helck (1957), UrkundenIV, 1555, 16 [=GF n 7]; $L G G \mathrm{~V}$, $10_{\mathrm{B}}-11_{\mathrm{B}}$ [29]; Koefoed-Petersen (1951), Catalogue des sarcophages, p. 17, pl. 25 [=GF n ${ }^{\circ}$ 8]; $L G G \mathrm{~V}, 10_{\mathrm{B}}-11_{\mathrm{B}}$ [34]; Davies (1923), Tomb of Puyemrê, p. 5, pl. 47 [=GF n ${ }^{\circ}$ ]; $L G G$ V, 10 ${ }_{\mathrm{B}}-11_{\mathrm{B}}$ [39]; Leitz (1994), Tagewählerei, pp. 434-435 [=GF n ${ }^{\circ}$ 9]; $L G G \mathrm{~V}, 10_{\mathrm{B}}-11_{\mathrm{B}}$ [41]; Junge (1987), Elephantine XI, p. 19 (n 3.1.6.1) [=GF n $\left.{ }^{\circ} 10\right] ; L G G$ V, $10_{\mathrm{B}}-11_{\mathrm{B}}$ [53]; Thiem (2000), Gebel es-Silsileh, p. 207, 334 [=GF n $\left.{ }^{\circ} 8\right]$.

${ }^{\dagger}$ For the GFs of this title in the LP, see $L G G \mathrm{~V}, 10_{\mathrm{B}}-11_{\mathrm{B}}$ [20]; Fakhry (1942), Bahria Oasis I, p. 88, pl. 34B: [=GF n ${ }^{\circ}$ 11]; $L G G \mathrm{~V}, 10_{\mathrm{B}}-11_{\mathrm{B}}$ [21]; Fakhry (1942), Bahria Oasis I, p. 158, pl. 51A: [=GF n 12 ]; $L G G \mathrm{~V}, 10_{\mathrm{B}}-11_{\mathrm{B}}$ [30]; Davies (1953), The Temple of Hibis, p. 19, pl. 18 (west wall): [=GF n ${ }^{\circ} 13$ ]; $L G G \mathrm{~V}, 10_{\mathrm{B}}-11_{\mathrm{B}}$ [38]; Gasse (1996), Les sarcophages, p. 210, pl. 58: [ $\left.=\mathrm{GF} \mathrm{n}{ }^{\circ} 14\right] ; L G G \mathrm{~V}, 10_{\mathrm{B}}-11_{\mathrm{B}}$ [40]; Naville (1892), The festival-hall of OsorkonII, pl. 12, 7: [=GF n ${ }^{\circ}$ 1]; $L G G \mathrm{~V}, 10_{\mathrm{B}}-11_{\mathrm{B}}$ [68]; Josephson (1999), Statues of the $X X V^{\text {th }}$ and $X X V I^{\text {th }}$ Dynasties, p. 75 $\left[=\mathrm{GF} \mathrm{n}^{\circ} 15\right]$.

${ }^{*}$ For the GFs of this title in the G.-R., see $L G G$ V, $10_{\mathrm{B}}-11_{\mathrm{A}}$ [7]; Beinlich (1991), Das Buchvom Fayum, 481-483, pl.

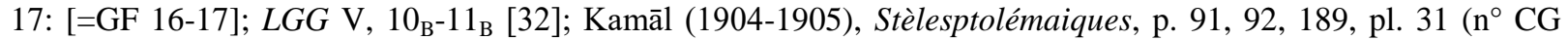

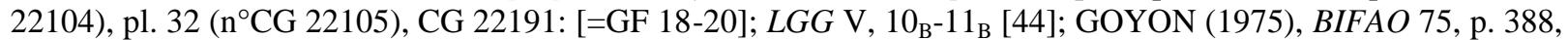
389: [=GF 21]; $L G G \mathrm{~V}, 10_{\mathrm{B}}-11_{\mathrm{B}}$ [55]; Rochemonteix (1987), Le temple d'Edfou I. 3, p. 331, 16 [=GF 22]; LGG V, $10_{\mathrm{B}}-11_{\mathrm{B}}$ [56]; Daumas (1959), Les Mammisis de Dendara, p. 141 ( $\left.{ }^{\circ} 24\right)$ : [=GF 23]; LGG V, 10 ${ }_{\mathrm{B}}-11_{\mathrm{C}}$ [59]; Osing (1998), HieratischePapyri, p. 241, pl. 24: [=GF 16]; LGG V, 10 ${ }_{\mathrm{B}}-11_{\mathrm{C}}$ [60]; Cauville (1997), Dendara X, 1, p. 86, 5; Cauville (1997), Les chapellesosiriennes, p. 48 (86): [=GF 23]; $L G G \mathrm{~V}, 10_{\mathrm{B}}-11_{\mathrm{C}}$ [63]; Chassinat (1928), Émile, Le temple d'EdfouIII, p. 107, 5: [=GF 25]; LGG V, 10슬 $11_{\mathrm{C}}$ [66]; Cauville (1997), Dendara X, 1, p. 360, 11, pl. 197; Cauville (1997), Les chapellesosiriennes, p. 195: [=GF 26]; LGG V, 11 $\mathrm{C}$ [2]; Brugsch (1891), altägyptischerDenkmäler, p. 1576: [=GF 27]; LGG V, 11, [5]; Cauville (2000), Dendara III: Traduction, pp. 70-

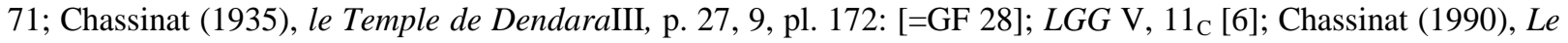
Temple d'EdfouII, 2, 289, 6, pl. 45c: [=GF 29]. 
International Journal of Heritage, Tourism and Hospitality Vol. (13), No. (1), March, 2019 By: Faculty of Tourism and Hotels, Fayoum University

\begin{tabular}{|c|c|c|c|}
\hline \multirow{2}{*}{ (12) } & \multirow{2}{*}{ «nb phty: Lord of might »" } & \multirow{2}{*}{$\bigsqcup_{9}^{9}$} & LP \\
\hline & & & $H 3$ \\
\hline (13) & $\begin{array}{l}\ll n b M 3 n w^{+}: \text {Lord of } M 3 n w \text {-Western } \\
\text { Mountain } »^{\ddagger}\end{array}$ & 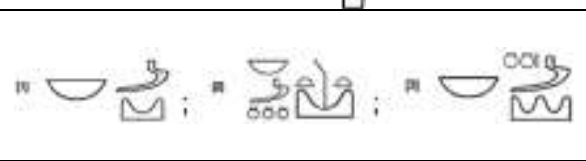 & $\begin{array}{c}\text { G.-R. } \\
\dot{H}^{3} \\
\dot{H}^{3}{ }^{3}\end{array}$ \\
\hline \multirow{2}{*}{ (14) } & \multirow{2}{*}{ «ntr ?3: Great god» } & \multirow{2}{*}{ "90; } & $\begin{array}{c}\mathrm{LP}^{\S} \\
\text { G. }^{\S} \text { R. }^{* *}\end{array}$ \\
\hline & & & $\begin{array}{c}H_{3}^{3} \\
\dot{H} 3^{3} 3 \\
\end{array}$ \\
\hline \multirow{2}{*}{$(15)$} & \multirow{2}{*}{$\ll n t r$ ? $3(m) 3 b d w$ : Great god in Abydos } & \multirow{2}{*}{$\left.9 \hat{0} \frac{0}{4}\right]_{\triangle}^{\infty}$} & LP \\
\hline & & & $H 3$ \\
\hline \multirow{2}{*}{ (16) } & \multirow{2}{*}{$\begin{array}{l}\text { «ntr ? } m \text { Imntt: Great god in the } \\
\text { West» }\end{array}$} & \multirow{2}{*}{ 위 } & G.-R. \\
\hline & & & $H 3$ \\
\hline \multirow{2}{*}{ (17) } & \multirow{2}{*}{ 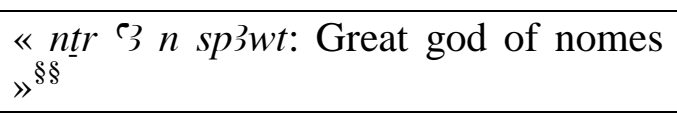 } & \multirow{2}{*}{$9 \hat{0} \frac{\text { m m }}{11}$} & G.-R. \\
\hline & & & $H 3$ \\
\hline \multirow{2}{*}{ (18) } & \multirow{2}{*}{ «ntr mnh: Potent god » } & \multirow{2}{*}{90} & G.-R. \\
\hline & & & $H_{3} 3$ \\
\hline \multirow{2}{*}{ (19) } & \multirow{2}{*}{$\begin{array}{l}\text { «w mntyw: He who strikes the } \\
M n t y w \text {-tribe } » " \dagger\end{array}$} & \multirow{2}{*}{ 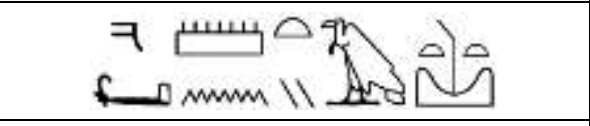 } & G.-R. \\
\hline & & & $H 3$ \\
\hline \multirow{2}{*}{$(20)$} & \multirow{2}{*}{$\begin{array}{l}\text { « Hw hlswt: He who strikes the } \\
\text { foreign Lands » }\end{array}$} & \multirow{2}{*}{$\exists \underset{\sim M}{M}$} & G.-R. \\
\hline & & & $H 3{ }^{3} 3$ \\
\hline \multirow{2}{*}{ (21) } & \multirow{2}{*}{ «Hry wpt: Master of judgment» ${ }^{\S \S}$} & \multirow{2}{*}{$\underset{2 \pi}{20}$} & LP \\
\hline & & & $H 3$ \\
\hline
\end{tabular}

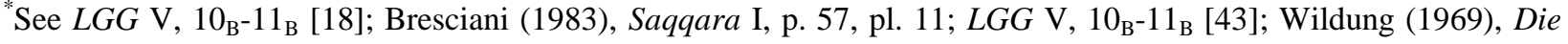
Rolle ägyptischerKönige, p. 79, 80, pl. 7, $8\left(\mathrm{n}^{\circ}\right)$.

'It is a mountainous and mysterious region of the Libyan desert, to the west of Egypt, where went down the sun and the moon and where lived the dead, see Gauthier (1926), Dictionnaire des nomsgéographiques III, p. 43.

${ }^{\ddagger}$ See $L G G \mathrm{~V}, 10_{\mathrm{B}}-11_{\mathrm{B}}$ [52]; Junker (1958), Tempels der Isis in Philä, p. 16, pl. 8: [=GF 1]; LGG V, 10 $0_{\mathrm{B}}-11_{\mathrm{B}}$ [54]; Chassinat (1933), Émile, Le temple d'EdfouVIII, 77, 3; Kurth (1998), EdfouVIII,p. 138: [=GF 2]; LGG V, 11. [6]; Chassinat (1990), Le Temple d'EdfouII, 2, 289, 6, pl. 45c: [=GF 3].

${ }^{\S}$ See $L G G \mathrm{~V}, 10_{\mathrm{B}}-11_{\mathrm{B}}$ [30]; Davies (1953), The Temple of Hibis, p. 19, pl. 18 (west wall): [=GF 1].

${ }^{* *}$ See $L G G \mathrm{~V}, 10_{\mathrm{B}}-11_{\mathrm{C}}$ [60]; Cauville (1997), Dendara X, 1, p. 86, 5; Cauville (1997), Les chapelles osiriennes, p. 48 (86); LGG V, 10 B $1_{\mathrm{C}}$ [66]; Cauville (1997), Dendara X, 1, p. 360, 11, pl. 197; Cauville (1997), Les chapelles osiriennes, p. 195: [=GF 1]; LGG V, 11, [5]; Cauville (2000), Dendara III: Traduction, pp. 70-71; Chassinat (1935), le Temple de DendaraIII, p. 27, 9, pl. 172: [=GF 2].

${ }^{\dagger}$ See $L G G$ V, $10_{\mathrm{B}}-11_{\mathrm{B}}$ [20]; Fakhry (1942), Bahria Oasis I, p. 88, pl. 34B

${ }^{+}$See $L G G \mathrm{~V}, 10_{\mathrm{B}}-11_{\mathrm{B}}$ [52]; Junker (1958), Tempels der Isis in Philä, p. 16, pl. 8.

${ }^{\S}$ See LGG V, 10 B $^{-11_{\mathrm{C}}}$ [57]; Cauville (2004), DendaraV-VI, p. 112, 113;Chassinat (1947), Le Temple de DendaraV, p. $30,9$.

See $L G G \mathrm{~V}, 11_{\mathrm{C}}$ [5]; Cauville (2000), Dendara III: Traduction, pp. 70-71; Chassinat (1935), le Temple de DendaraIII, p. 27, 10, pl. 172.

${ }^{\dagger}$ See $L G G$ V, 10 B $^{-11_{\mathrm{C}}}$ [60]; Cauville (1997), Dendara X, 1, p. 86, 5; Cauville (1997), Les chapelles osiriennes, p. 48 (86).

WSee LGG V, 11 ${ }_{\mathrm{C}}$ [5]; Cauville (2000), Dendara III: Traduction, pp. 70-71; Chassinat (1935), le Temple de DendaraIII, p. 27, 9, pl. 172.

${ }^{\S \S}$ See $L G G \mathrm{~V}, 10_{\mathrm{B}}-11_{\mathrm{B}}$ [18]; Bresciani (1983), Saqqara I, p. 57, pl. 11. 
International Journal of Heritage, Tourism and Hospitality Vol. (13), No. (1), March, 2019 By: Faculty of Tourism and Hotels, Fayoum University

\begin{tabular}{|c|c|c|c|}
\hline \multirow{2}{*}{$(22)$} & \multirow{2}{*}{$\begin{array}{l}\text { «Hryr3-st } 3 w: \text { Master of the necropolis } \\
{ }_{\star}^{*}\end{array}$} & \multirow{2}{*}{ 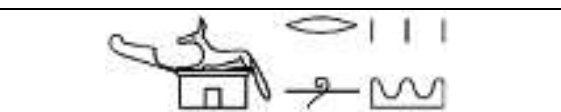 } & LP \\
\hline & & & $\mathrm{H3}$ \\
\hline \multirow{2}{*}{ (23) } & \multirow{2}{*}{ «Hry ${ }^{\top} b . w y:$ Master of Two Horns $»^{\dagger}$} & & LP \\
\hline & & & $H 3$ \\
\hline \multirow{2}{*}{ (24) } & \multirow{2}{*}{$\begin{array}{l}\text { «Hry-ib Iwnt: He who resides in } \\
\text { Iounet» } \$\end{array}$} & & G.-R. \\
\hline & & & $\mathrm{H}_{3} \mathrm{C}$ \\
\hline \multirow{2}{*}{$(25)$} & \multirow{2}{*}{$\begin{array}{l}\text { «Hry-ib } N 3{ }^{C} r r f^{* *}: \text { He who resides in } \\
\text { Naârref } »^{\dagger \dagger}\end{array}$} & \multirow{2}{*}{$\begin{array}{l}\vec{\gamma}=100 \\
80 \% \Leftrightarrow 0\end{array}$} & LP \\
\hline & & & $H 3$ \\
\hline \multirow{2}{*}{ (26) } & \multirow{2}{*}{$\begin{array}{l}\text { «Hry-ib } \mathrm{Hbt}^{\dagger+}: \text { He who resides in } \\
\text { Hibis } \$ \$\end{array}$} & \multirow{2}{*}{ ?ִ } & LP \\
\hline & & & $H 3$ \\
\hline \multirow{2}{*}{ (27) } & \multirow{2}{*}{$\begin{array}{l}\ll_{*} \text { Hry-tp Mntiw: Chief of Mntyw-tribe } \\
»\end{array}$} & \multirow{2}{*}{ शिण } & G.-R. \\
\hline & & & $H 3-e_{3}$ \\
\hline \multirow[b]{2}{*}{ (28) } & \multirow{2}{*}{ «Hry-tp $m 3^{\circledR} t$ : Chief of right ${ }^{\dagger \dagger \dagger}$} & \multirow{2}{*}{ 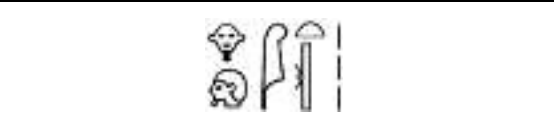 } & NK \\
\hline & & & $\begin{array}{l}\text { H3-Imn- } \\
W n-n f r\end{array}$ \\
\hline \multirow[t]{2}{*}{ (29) } & \multirow[t]{2}{*}{ «hsktp: He who cuts off the head» } & \multirow{2}{*}{ 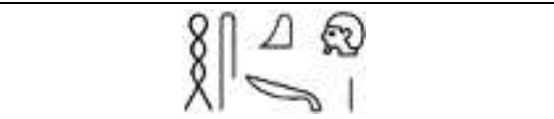 } & LP \\
\hline & & & $H 3$ \\
\hline \multirow[t]{2}{*}{$(30)$} & \multirow{2}{*}{ 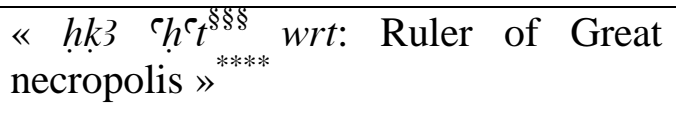 } & \multirow{2}{*}{ ? } & G.-R. \\
\hline & & & $\mathrm{H}_{3}-\mathrm{C}_{3}$ \\
\hline \multirow[t]{2}{*}{ (31) } & \multirow{2}{*}{$\begin{array}{l}\text { «hk3 h3swt: Ruler of the foreign } \\
\text { Lands» }{ }^{\dagger \dagger \dagger}\end{array}$} & \multirow{2}{*}{$?_{1}^{\mathrm{N}}$} & G.-R. \\
\hline & & & $\mathrm{H}_{3}-\mathrm{C}_{3}$ \\
\hline \multirow[t]{2}{*}{ (32) } & \multirow{2}{*}{$\begin{array}{l}\text { «hk了 } \underline{T} m h w^{\ddagger \ddagger \ddagger \ddagger}: \text { Ruler of of the } \\
\text { Libyans } » \S \S \S\end{array}$} & \multirow{2}{*}{ 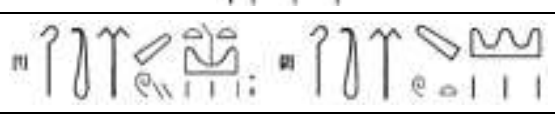 } & G.-R. \\
\hline & & & $\mathrm{H} 3, \mathrm{H} 3-\mathrm{C}_{3}$ \\
\hline
\end{tabular}

"See $L G G \mathrm{~V}, 10_{\mathrm{B}}-11_{\mathrm{B}}$ [43]; Wildung (1969), Die Rolle ägyptischerKönige, p. 79, 80, pl. 7, 8 (nº).

${ }^{\dagger}$ See $L G G \mathrm{~V}, 10_{\mathrm{B}}-11_{\mathrm{B}}$ [43]; Wildung (1969), Die RolleägyptischerKönige, p. 79, 80, pl. 7, $8\left(\mathrm{n}^{\circ}\right)$.

I Iwnt was the ancient Egyptian name of the capital of the VIth Nome of Upper Egypt, now Dendara (دندرة), see Gauthier. 1925, Dictionnaire des noms géographiques I, p. 56.

${ }^{\S}$ See $L G G \mathrm{~V}, 11_{\mathrm{C}}$ [5]; Cauville (2000), Dendara III: Traduction, pp. 70-71; Chassinat (1935), le Temple de DendaraIII, p. 27, 9, pl. 172.

**NAarrf is a Locality very often cited on religious texts as being in relation with Osiris, the god of the dead. There was the necropolis of the chief town of the $20^{\text {th }}$ nome of Upper Egypt Heracleopolis Magna, today إهناسيا المدينة The reading of this name has varied a lot and its meaning is unclear: it has generally been translated "the place where nothing grows", but it would be a strange name for a place where was precisely preserved the sacred tree of the nome, see H. Gauthier (1925), Dictionnaires des nomsgéographiques I, pp. 66-67.

${ }^{\dagger}$ See $L G G \mathrm{~V}, 10_{\mathrm{B}}-11_{\mathrm{B}}$ [37]; Perdu (1994), Musée de Picardie, pp. 112-113.

\#0btwasthe Egyptianname of the capital of the great oasis of El-Kharga, nowHibis (هيب), see Gauthier (1927), Dictionnaire des noms géographiques IV, p. 4.

${ }^{\S \S}$ See $L G G \mathrm{~V}, 10_{\mathrm{B}}-11_{\mathrm{B}}$ [30]; Davies (1953), The Temple of Hibis, p. 19, pl. 18 (west wall).

${ }^{* * * *}$ See $L G G \mathrm{~V}, 11_{\mathrm{C}}$ [6]; Chassinat (1990), Le Temple d'Edfou II, 2, 289, 6, pl. 45c.

${ }^{\dagger \dagger}$ See Hayes (1939), The burial chamber of the treasurer Sobk-mose, p. 19 and pl. 5.

${ }^{1+}$ See $L G G \mathrm{~V}, 10_{\mathrm{B}}-11_{\mathrm{B}}$ [38];Gasse (1996), Les sarcophages, p. 210, pl. 58.

${ }^{\S \S}$ For aHat, see supra, note 31.

${ }^{* * * * *}$ See $L G G \mathrm{~V}, 11_{\mathrm{C}}$ [6]; Chassinat (1990), Le Temple d'Edfou II, 2, 289, 6, pl. 45c.

${ }^{\dagger \dagger}$ See $L G G \mathrm{~V}, 11_{\mathrm{C}}$ [2]; Brugsch (1891), altägyptischerDenkmäler, p. 1576.

NitSee Gauthier (1929), Dictionnaire des noms géographiques VI, pp. 75-76.

${ }^{\$ \$ \$}$ See $L G G \mathrm{~V}, 10_{\mathrm{B}}-11_{\mathrm{B}}$ [54]; Chassinat (1933), Émile, Le temple d'Edfou VIII, 77, 3; Kurth (1998), Edfou VIII,p. 138: [=GF 1]; $L G G \mathrm{~V}, 11_{\mathrm{C}}$ [6]; Chassinat (1990), Le Temple d'Edfou II, 2, 289, 6, pl. 45c [=GF 2]. 
International Journal of Heritage, Tourism and Hospitality Vol. (13), No. (1), March, 2019 By: Faculty of Tourism and Hotels, Fayoum University

\begin{tabular}{|c|c|c|c|}
\hline (33) & $\begin{array}{l}\text { «hbhb } \stackrel{S}{S}_{3 s w^{*}: \text { He who trample down }} \\
\text { the Bedouin tribes } »^{\dagger}\end{array}$ & 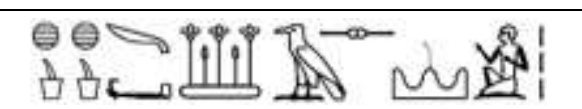 & $\frac{\mathrm{G} .-\mathrm{R} .}{H_{3}}$ \\
\hline \multirow[t]{2}{*}{ (34) } & \multirow{2}{*}{$\begin{array}{l}\text { «hnty Iw-nšny: He who presides over } \\
\text { the Island of-fury» }\end{array}$} & \multirow{2}{*}{ 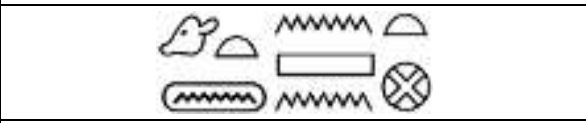 } & G.-R. \\
\hline & & & $H 3$ \\
\hline \multirow[t]{2}{*}{$(35)$} & \multirow{2}{*}{$\begin{array}{l}\text { «hnty pr Hr-it } n=f h \underline{d} d t \text { He who } \\
\text { presides over the sanctuary of Horus } \\
\text { who takes possession of the white } \\
\text { crown =Dendara»* }\end{array}$} & \multirow[b]{2}{*}{ 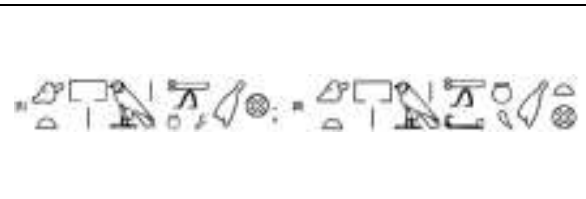 } & G.-R. \\
\hline & & & $H 3$ \\
\hline \multirow[t]{2}{*}{ (36) } & \multirow{2}{*}{$\begin{array}{l}\text { «s } 3 \underline{d} \text { it=f: the son who protects his } \\
\text { father» }\rangle^{\dagger \dagger}\end{array}$} & \multirow{2}{*}{ 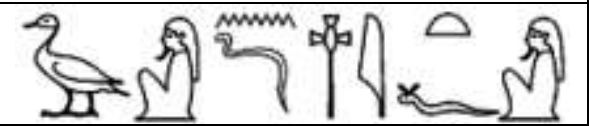 } & MK \\
\hline & & & $H r-H_{3}^{3}$ \\
\hline \multirow[t]{2}{*}{ (37) } & \multirow{2}{*}{ 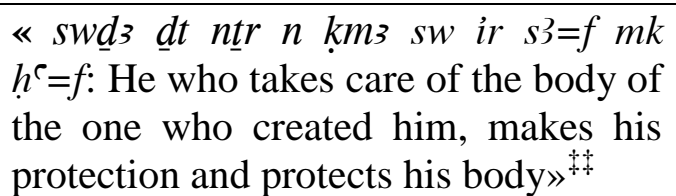 } & \multirow[b]{2}{*}{ 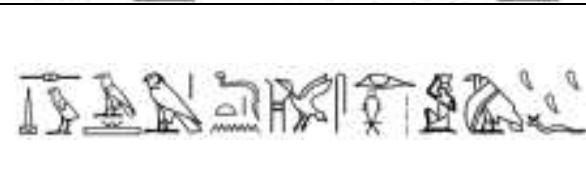 } & G.-R. \\
\hline & & & $H 33$ \\
\hline \multirow[t]{2}{*}{ (38) } & \multirow[t]{2}{*}{ «sniwsrt: He who cuts off the neck ${ }^{\S \S}$} & & LP \\
\hline & & 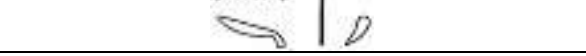 & $H 3$ \\
\hline \multirow[t]{2}{*}{ (39) } & \multirow{2}{*}{$\begin{array}{l}\text { «shm dmpt: Puissance who touches } \\
\text { the sky» }\end{array}$} & \multirow{2}{*}{$89 \odot$} & G.-R. \\
\hline & & & $H 3$ \\
\hline \multirow[t]{2}{*}{$(40)$} & \multirow[t]{2}{*}{$\ll k 3-?:$ High of arm $»^{\dagger \dagger}$} & \multirow{2}{*}{$\Delta$ แ⿺ } & G.-R. \\
\hline & & & $H^{3}$ \\
\hline \multirow[t]{2}{*}{ (41) } & \multirow[t]{2}{*}{$\ll d i{ }^{\ulcorner} n h:$ He who gives life $»^{+t}$} & & LP \\
\hline & & & $H 3$ \\
\hline \multirow[t]{2}{*}{$(42)$} & \multirow{2}{*}{$\begin{array}{l}\text { «di }{ }^{\complement} n h w 3 s n b \text { mi } R^{\complement} d t \text { : He who gives } \\
\text { life and prosperity like Ra every day } \\
\S_{\S \S}\end{array}$} & \multirow{2}{*}{$\Delta+1900$} & LP \\
\hline & & & $H 3$ \\
\hline
\end{tabular}

"5Asw is aterm used to refer generally to nomadic and plundering populations. The Bedouin tribes encamped in the tents and wandered on the edge of the deserts from the borders of Egypt to the north of Lebanon and around Aleppo. The Egyptians applied the name to all those barbarians who came from its northeast border, see Gauthier (1928), Dictionnaire des nomsgéographiques V, pp. 106-107.

${ }^{\dagger}$ See $L G G \mathrm{~V}, 10_{\mathrm{B}}-11_{\mathrm{B}}$ [52]; Junker (1958), Tempels der Isis in Philä, p. 16, pl. 8.

${ }^{*}$ IW-nSny: the island of fury, or of misfortune »is a territory's name belonging to the temple of Horus at Edfu, see Gauthier (1925), Dictionnaires des nomsgéographiques I, p. 46.

${ }^{\S}$ See $L G G$ V, $10_{\mathrm{B}}-11_{\mathrm{B}}$ [54]; Chassinat (1933), Émile, Le temple d'Edfou VIII, 77, 3; Kurth (1998), Edfou VIII,p. 138.

${ }^{* *}$ See $L G G \mathrm{~V}, 10_{\mathrm{B}}-11_{\mathrm{C}}$ [60]; Cauville (1997), Dendara X, 1, p. 86, 5; Cauville (1997), Les chapelles osiriennes, p. 48 (86): [=GF 1]; $L G G$ V, $10_{\mathrm{B}}-11_{\mathrm{C}}$ [66]; Cauville (1997), Dendara X, 1, p. 360, 11, pl. 197; Cauville (1997), Les chapelles osiriennes, p. 195 [=GF 2].

${ }^{\dagger}$ See LGG V, 272 C [2]; Faulkner (1969), PyramidTexts, p. 170; Sethe (1960), Pyramidentexte, Utterance 483 (Pyr. § 1013d).

${ }^{\#}$ See $L G G$ V, 11 1 [5]; Cauville (2000), Dendara III: Traduction, pp. 70-71; Chassinat (1935), le Temple de DendaraIII, p. 27, 10, pl. 172.

${ }^{\S \S}$ See $L G G \mathrm{~V}, 10_{\mathrm{B}}-11_{\mathrm{B}}$ [38];Gasse (1996), Les sarcophages, p. 210, pl. 58.

${ }^{* * *}$ See $L G G$ V, 10 ${ }_{\mathrm{B}}-11_{\mathrm{C}}$ [66]; Cauville (1997), Dendara X, 1, p. 360, 11, pl. 197; Cauville (1997), Les chapelles osiriennes, p. 195.

${ }^{\dagger \dagger}$ See $L G G \mathrm{~V}, 10_{\mathrm{B}}-11_{\mathrm{B}}$ [54]; Chassinat (1933), Le temple d'EdfouVIII, 77, 3; Kurth (1998), EdfouVIII,p. 138.

$+{ }_{\text {St }}$ See $L G G$ V, $10_{\mathrm{B}}-11_{\mathrm{B}}$ [20]; Fakhry (1942), Bahria Oasis I, p. 88, pl. 34B.

${ }^{\S \S}$ See $L G G \mathrm{~V}, 10_{\mathrm{B}}-11_{\mathrm{B}}$ [40]; Naville (1892), The festival-hall of OsorkonII, pl. 12, 7. 
International Journal of Heritage, Tourism and Hospitality Vol. (13), No. (1), March, 2019 By: Faculty of Tourism and Hotels, Fayoum University

\begin{tabular}{|c|c|c|c|}
\hline \multirow[t]{2}{*}{ (43) } & \multirow{2}{*}{$\begin{array}{l}\text { «i ‘nh mi } R^{\complement} d t \text { : He who gives life } \\
\text { like Ra forever»» }\end{array}$} & & LP \\
\hline & & & $H 3$ \\
\hline \multirow[t]{2}{*}{ (44) } & \multirow{2}{*}{$\begin{array}{l}\text { «di=f htpw nbwt } n \text { Wsir hnty-jmntyw: } \\
\text { He who gives all the offerings to } \\
\text { Osiris 'Foremost of the Westerners }{ }^{\dagger}\end{array}$} & \multirow{2}{*}{ 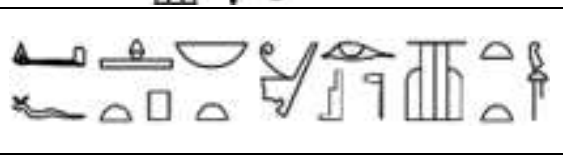 } & G.-R. \\
\hline & & & $H^{3}$ \\
\hline \multirow[t]{2}{*}{ (45) } & \multirow{2}{*}{$\begin{array}{l}\text { «di msnỉ } f m \text { Sttyw } w^{\ddagger} h s y: \text { He who point } \\
\text { his knife in the miserable Asiatic } \\
\text { people } »\end{array}$} & \multirow{2}{*}{ 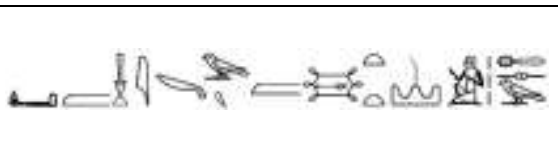 } & G.-R. \\
\hline & & & $H^{3}$ \\
\hline \multirow[t]{2}{*}{$(46)$} & «dgi hnty-imntyw: Gardian of & \multirow{2}{*}{ E] } & NK \\
\hline & $\begin{array}{l}\text { Foremost of the Westerners (=Osiris) } \\
{ }_{* *}\end{array}$ & & $H 3$ \\
\hline
\end{tabular}

\section{Discussion and Results}

After this enumeration of the different names and epithets applied to the god Ha, certain points are determined as follows. It is now evident that the study of Ha's denominations is still in its infancy because the documents coming from the VII ${ }^{\text {th }}$ nome of Lower Egypt and the Western Desert of Egypt and their oases are very little or not published. Further excavations particularly in the area around Ha's principal cult centers and further studies of collections with Egyptian and Levantine objects would inevitably increase the list of Ha's names and titles proposed here.

The historical development of Ha's cult, starting from the OK, was characterized by such increasing associations with other deities, particularly Amon, Horus, Sopodand Soker. Due to such associations, Ha gained some diffusion, both in terms of geographical distribution and semantic contexts.

The occurrence and use of Ha's names and epithets don't seem to be geographically restricted. His traditional main cult centers in theVII ${ }^{\text {th }}$ nome of Lower Egypt and the Western Desert of Egypt including their oases revealed through the time being discussed; merely a few number of his known denominations. The Upper Egyptian inscriptions contributed more thanthose of Lower Egypt to the list of Ha's names and epithets. It is significant to indicate that the epithets of Ha outside Egypt cannot be noted thus far.

Ha was the supervisor of the production of commodities in the desert regions ${ }^{\dagger \dagger}$. This role is well explained by the OK officials' title: «jmj-hnt H3: Follower of Ha »which probably referred to the god's function. His protection extended to practical help for the deceased in the underworld.Ha was therefore the god who protected against hunger and provided nourishment in the underworld.He is entitled «di=f htp nbt $n$ Wsir hnty-imntyw: He who gives all the offerings to Osiris Khenti-Amentiu "Foremost of the Westerners" ${ }^{+4}$. This role is well explained in the Pyramid of Unis; utterance PT 204 (Pyr. § 119b). The text says:

*See $L G G \mathrm{~V}, 10_{\mathrm{B}}-11_{\mathrm{B}}$ [30]; Davies (1953), The Temple of Hibis, p. 19, pl. 18 (west wall).

${ }^{\dagger}$ See $L G G \mathrm{~V}, 10_{\mathrm{B}}-11_{\mathrm{B}}$ [32]; Kamāl (1904-1905), Stèlesptolémaiques, p. 189, pl. 31 (nº CG 22191).

${ }^{*}$ 4Ttywis a toponym given, from the ancient historical ages, to the region located to the north-east and east of Egypt, Sinai, Palestine and Syria, See Gauthier (1928), Dictionnaire des nomsgéographiques V, pp. 95-96.

${ }^{\S}$ See $L G G \mathrm{~V}, 10_{\mathrm{B}}-11_{\mathrm{B}}$ [52]; Junker (1958), Tempels der Isis in Philä, p. 16, pl. 8.

${ }^{* * *}$ See $L G G \mathrm{~V}, 10_{\mathrm{B}}-11_{\mathrm{B}}$ [17]; Seele (1959), The Tomb of Tjanefer, pl. 31.

"SeeAltenmüller(2013). "ZuzweiTiteln des AltenReiches, einVorschlagzuihrerInterpretation. Die Titel des „Priesters der Heqet“" und des „Gefolgsmanns des Ha", pp. 1-14.

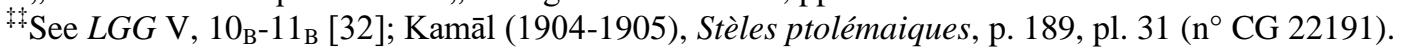




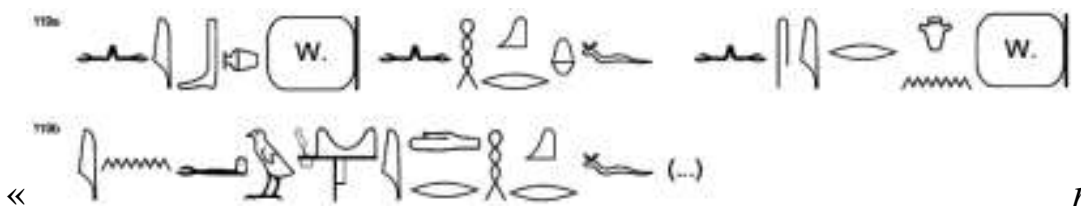

$n n i b(W.) \ln n h k r=f n n$ sy $r i b n$

(W.)I in ' $w$ H ${ }^{3}$ idr $h k r=f(\ldots)$ : Unis will not thirst, Unis will not hunger: it will not be against the heart of Unis. Ha's arms are what repel his hunger»* .

In his familiar epithets «? phty: Great of might», «wr šfyt : Great of terror», «nb phty: Lord of might », «ntr mnh : Potent god », «Hry `b.wy: Master of Two Horns », « hsk tp: He who cuts off the head », «sni wsrt: He who cuts off the neck », «shm dm pt: Puissance who touches the sky » and «k3-?: High of arm »,Ha defended Egypt against its foes. This is expressed in his common

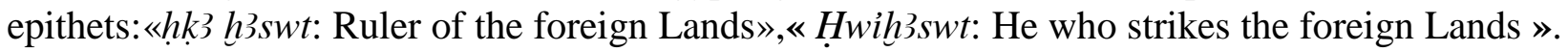
Hence the desert deity's appellations «wdi-r-srk $m$ Fnhw: He who puts an end to Asiatic people », «di msnỉ=f $m$ Sttyw hlsy: He who point his knife in the miserable Asiatic people »and «hbhb $\breve{S}_{3 S w}$ : He who trample down the Bedouin tribes »,imply his protective role against the Bedouin tribes and Asiatic people.

In parallel, the «ntr $93 \mathrm{~m}$ Imntt: Great god in the West »provides protection for the western deserts and their oases from enemies such as desert nomads and invading Libyan tribesmen under his epithet «Ptpt Mntyw: He who destroys the Mntyw-tribe », «nb M3nw: Lord of M3nwWestern Mountain », « $H w$ mntyw: He who strikes the Mntyw-tribe » and «hk $3 \underline{T} \underline{T} h w$ : Ruler of of the Libyans ».

Additionally, Ha was also associated with the underworld as he is called: «Imy $d w 3 t$ : He who is in the netherworld », "Iry ' $h^{\top} t \underline{d}$ srt: Guardian of the sacred necropolis », «Nb Imntt: Lord of the West » «Hryr3-st $\underline{3} w$ : Master of the necropolis », «ntr 93 m Imntt: Great god in the West » and « hlk 3 ‘ h`t wrt: Ruler of Great necropolis ».

Ha was the defender of Osiris Khentamenti against Seth, who by the time of the Ptolemies had become the personification of evil. This role is well explained in the Papyrus of Imhotep, son of Pshentohe, New York MMA 35.9.21, which dates back to the Ptolemaic Period. The text says:
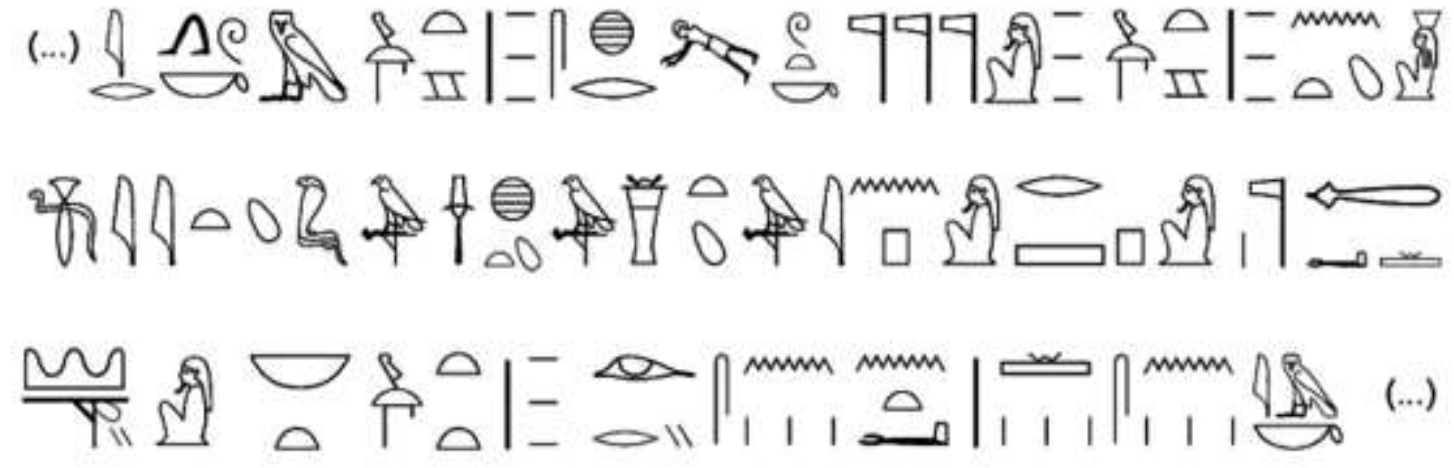

" $\quad$ (...)ir

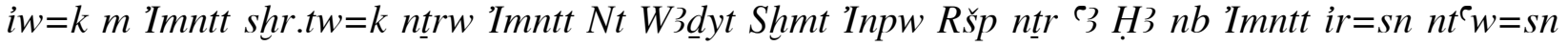
$m=k(\ldots)$ : (...) If you come from the West, the gods of the West, Neith, Wadjit, Sachmet, Bastet, Anubis, Reshef the great god (and) Ha Lord of the West, will throw you down. They will fulfill their destination concerning you(...) ». In his epithets, Ha is entitled «ir nhww n Sr-hadt: He who makes effective protection for the Prince of the White Crown (= Osiris) » and «dgi hnty-imntyw: Gardian of Foremost of the Westerners (=Osiris) ».

"See Allen (2005), Pyramid Texts, p. 29; Faulkner (1969), Pyramid Texts, p. 37; Sethe (1960), Pyramidentexte, Utterance 204 (Pyr. § 119a-b). 
His protective role extended not only to the Creator god «

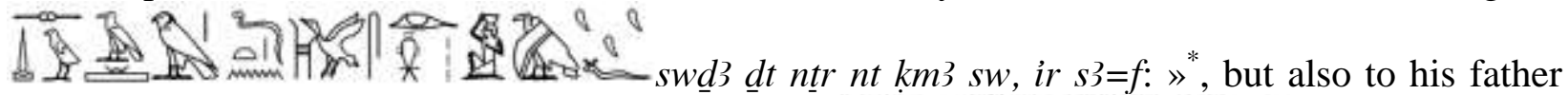
«s $n \underline{d}$ it=f: the son who protects his father» and « $i t=f, d r \underline{d} w n b r=f$ : Potent god who makes protection for his father and repulses all evil from him $»^{\dagger}$.

Ha had strong links with the royal power because he helped the pharaoh to achieve his political and religious mission by approaching him to his people: $r d i=i \quad m r w t=k m$ ib $n b$ mi Hr hr mnty $n$ 3st: I place your love in all heart like Horus on the knees of Isis $»^{*}$.

Ha also offers protection to the king. There are many occasions when the god had to be reminded of this protection for the pharaoh. Ha says to the king: « $\longrightarrow$ शी $r=k$, irr $\underline{d} w r=k m n m t^{\S}$ : I give to you the might against those who plot all evil against you and anyone does evil against you, (will go) to the place of judgment» ${ }^{* *}, \ll$

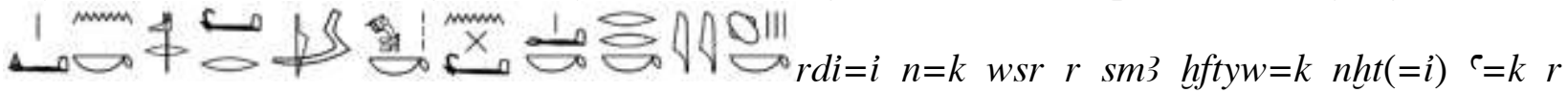
$r k w w=k$ : I give to you the power to smite your enemies. I strengthen your arm against your adversaries », « ० की $s n h t=i^{\complement}=k r b \underline{t} n w w=k$ : I give to you might like Son of Isis (=Horus) and I make your arm strong against your foes $»$, , « Majesty is together with your arms »s and ${ }^{\S s}$ $s n h t=i^{\complement} . w y=k r h f t y w m h 3 w=k$ : I make strong your arms against your enemies in your reign ${ }^{* * *}$. Finally the aspect of $\mathrm{Ha}$ as a funerary god is especially prominent in the regions of the west where the necropolis was under his safekeeping. As «Lord of the west », Ha is invoked as the only god in an offering formula in the tomb $\mathrm{n}^{\circ}$ (TT 39) of Puiemra, the second prophet of Amun under the reign of Hatshepsut ${ }^{\dagger \dagger}$. The text says: «

"SeeCauville (2000), Dendara III: Traduction, pp. 70-71; Chassinat (1935), le Temple de DendaraIII, p. 27, 9, pl. 172

†SeeCauville (2000), Dendara III: Traduction, pp. 70-71; Chassinat (1935), le Temple de DendaraIII, p. 27, 9, pl. 172

${ }^{\ddagger}$ SeeCauville (2000), Dendara III: Traduction, pp. 70-71; Chassinat (1935), le Temple de DendaraIII, p. 27, 9, pl. 172.

${ }^{\S} \mathrm{Nmt}$ is a toponymwhere the blood-eating god, one of the forty-two infernal tribunal judges, sacrificed his victims, see Gauthier (1926), Dictionnaire des nomsgéographiques III, p. 93.

${ }^{* *}$ See Junker (1958), Tempels der Isis in Philä, p. 16, pl. 8

†See Chassinat, Le temple d'EdfouVIII, p. 77, 3; Kurth (1998), EdfouVIII,p. 138.

"SeeChassinat,Le temple d'EdfouVIII, p. 77, 3;Kurth (1998), EdfouVIII,p. 138.

${ }^{\S}$ See Junker (1958), Tempels der Isis in Philä, p. 17, pl. 8.

${ }^{* * *}$ See Junker (1958), Tempels der Isis in Philä, p. 17, pl. 8.

${ }^{\dagger \dagger}$ See Davies (1923), Tomb of Puyemrê, p. 5, pl. 47 


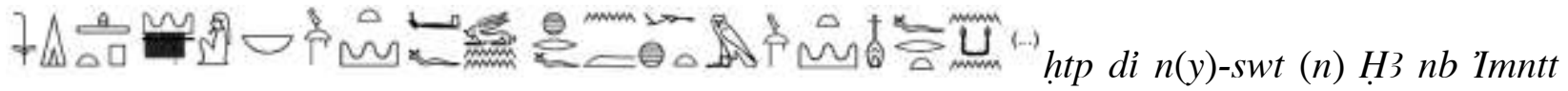
$d i=f$ wnn hr=f $n$ imy-ht $m$ 'Imntt nfrt $n k 3 n$ (...): An offering given by the king to Ha Lord of the West, that he may grant residence at his court as one of his train in the kindly West, to the ka of (...) ». This part of the formula indicates that the offering is seen as being under the auspices of the god Ha who is the patron deity of the local funerary establishment that actually provided the offering.

\section{Conclusion}

Ha was an important deity who hold several names « H3: HA, H3-Imn-Wn-nfr: HA-Amon-Wen-

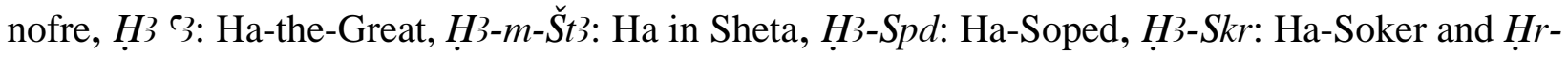
$H$ 3: Horus-HA »and diverse epithets which obviously reflect the different aspects and roles that he played in the Egyptian pantheon. His aspect as a funerary god was especially prominent in the regions of the west where the necropolis was under his safekeeping. Ha was at the same time the god who protected against hunger and provided nourishment in the underworld.

In addition, the «Nb Imntt: Lord of the West» was thought to protect Egypt specially the western deserts and their oases from enemies such as desert nomads, invading Libyan tribesmen, Asiatic people and Bedouin tribes. Ha was a protector of the god Osiris, the Creator god, his father as well as the pharaoh.

In Brief, as a terrifying god, a war god, a god with strong links with the royal power, Ha has a wide and diverse field of activities; his identification allows the veil to be slight lifted on some elements of Egyptian religion.

\section{Bibliography}

Allen, J. P. (2005). The Ancient Egyptian Pyramid Texts, Writings from the Ancient World 23, Atlanta: Society of Biblical Literature.

Altenmüller, H. (2013). "ZuzweiTiteln des AltenReiches, einVorschlagzuihrerInterpretation. Die Titel des „Priesters der Heqet“ und des „Gefolgsmanns des Ha”. In M. Bárta\& H. Küllmer (Eds.), Diachronic trends in ancient Egyptian history: Studies dedicated to the memory of Eva Pardey, pp. 1-14, Prague: Charles University, Faculty of Arts.

Beinlich, Horst (1991), Das Buchvom zumreligiösenEigenverständtniseinerägyptischenLandschaft, Wiesbaden: Otto Harrassowitz.

Borchardt, Ludwig (1907), Das Grabdenkmal des Königs Ne-user-re',Ausgrabungen der Deutschen Orient-Gesellschaft in Abusir 1902-1904 I, Leipzig : J. C. Hinrichs.

Bresciani, Edda et alii. (1983),Saqqara. I, Tomba di Boccori: la galleria di Padineitvisir di Nectanebo I, SupplementoaEgitto e Vicino Oriente III 1980. Seriearcheologica 2, Pisa: Giardini Ed.

Brugsch, Heinrich (1891), Bautexte und InschriftenverschiedenenInhaltesaltägyptischerDenkmäler, TIA 6, Leipzig: Hinrichs.

Brunner-Traut, Emma and Brunner, Hellmut (1981), Die ÄgyptischeSammlung der UniversitätTübingen, Mainz am Rhein: v. Zabern.

Buck, Adriaan de (1961), The Egyptian Coffin Texts VII: Texts of Spells, 787-1185, OIP 87, Chicago: The University of Chicago Press.

Buck, Adriaan de (1956), The Egyptian Coffin Texts VI: Texts of Spells, 472-786, OIP 81, Chicago: The University of Chicago Press.

Buck, Adriaan de (1954), The Egyptian Coffin Texts V: Texts of Spells, 355-471, OIP 73, Chicago: The University of Chicago Press. 
Buck, Adriaan de (1951), The Egyptian Coffin Texts IV: Texts of Spells, 268-354, OIP 67, Chicago: The University of Chicago Press.

Buck, Adriaan de (1938), The Egyptian Coffin Texts II: Texts of Spells, 76-163, OIP 49, Chicago: The University of Chicago Press.

Buck, Adriaan de (1935), The Egyptian Coffin Texts I: Texts of Spells, 1-75, OIP 34, Chicago: The University of Chicago Press.

Buhl, Marie-Louise (1959), The Late Egyptian Anthropoid Stone Sarcophagi, Nationalmuseetsskrifter. Arkæologisk-historiskrække 6, Copenhague: Nationalmuseet.

Cauville, Sylvie (2004), Dendara V-VI, Les cryptes du temple d'Hathor, OLA 131-132, Leuven; Paris; Dudley: Peeters.

Cauville, Sylvie (2000), Dendara III: Traduction, OLA 95, Leuven; Paris; Dudley: Peeters.

Cauville, Sylvie (1997), Le Temple de Dendara: les chapelles osiriennes. Partie 1, Transcription et traduction, BiEtud117, Le Caire: IFAO.

Cauville, Sylvie (1997), Le Temple de Dendara: Les chapelles osiriennesmDendara, X/1-2, Le Caire: IFAO.

Chassinat, Émile (1990),Le Temple d'Edfou II, 2. Deuxième édition revue et corrigée par Sylvie Cauville et Didier Devauchelle, MMAF 11, Le Caire: IFAO.

Chassinat, Émile and Rochemonteix, Maxence de (1987), Le temple d'Edfou II, 1. Deuxième édition revue et corrigée par Sylvie Cauville et Didier Devauchelle, MMAF 11, Le Caire: IFAO.

Chassinat, Émile (1947 and 1952), Le Temple de Dendara V. Premier fascicule: Texte and Deuxième fascicule: Planches, Dendara 5/1, Le Caire: IFAO.

Chassinat, Émile (1935), « Textes provenant du Sérapéum de Memphis », RecTrav XXI, Paris, 1899, pp. 56-73.

Chassinat, Émile (1935), le Temple de DendaraIII, Le Caire: IFAO ( $2^{\text {nd }}$ edition 2004).

Chassinat, Émile (1933), Le temple d'Edfou VIII, MMAF 25, Le Caire: IFAO, (2 ${ }^{\text {nd }}$ edition 2009).

Chassinat, Émile (1931), Le temple d'Edfou VI, MMAF 23, Le Caire: IFAO, (2 ${ }^{\text {nd }}$ edition 2009).

Chassinat, Émile (1928), Le temple d'Edfou III, publié in extenso d'après les estampages recueillis par le marquis de Rochemonteix, MMAF 20, Le Caire: IFAO, ( $2^{\text {nd }}$ edition 2009).

Chassinat, Émile Gaston and Palanque, Charles (1911), Une campagne de fouilles dans la nécropole d'Assiout, MIFAO 24, Le Caire: IFAO.

Chassinat, Émile (1903), « Textes provenant du Sérapéum de Memphis (Suite) », RecTrav XXV, Paris, pp. 50-62.

Chassinat, Émile (1900), « Textes provenant du Sérapéum de Memphis (Suite)», RecTrav XXII, Paris, pp. 163-73.

Corteggiani, Jean-Pierre(2007), L'Égypte ancienne et ses dieux: dictionnaire illustré, Paris: Fayard.

Cruz-Uribe, Eugene (1988), Hibis Temple Project. Volume I, Translations, commentary, discussons and sign list, San Antonio, Texas: Van Siclen Books.

Ćwiek, Andrzej(2015), "Ha in Sheta", in: Z. E. Szafrański (ed.), Polish Archaeology in the Mediterranean 24, 2, Special Studies: Deir el-Bahari Studies, Warsaw, pp. 83-92.

Daumas, François (1959), Les Mammisis de Dendara, IFAO, Le Caire: IFAO.

Davies, Norman de Garis (1953), The Temple of Hibis in El Khargeh oasis. Part III, The Decoration, MMAEE XVII, New York: The Metropolitan Museum of Art.

Davies, Norman de Garis (1923), The Tomb of Puyemrê at Thebes. Volume II, The Chapels of Hope, RPTMS III, New York: The Metropolitan Museum of Art. 
Fakhry, Ahmed (1942), Bahria Oasis, Vol.1, The Egyptiandeserts, Cairo: Service des antiquités de l'Egypte.

Faulkner, Raymond Oliver (1977), The Ancient Egyptian Coffin texts II: Spells 355-787, Warminster: Aris\& Philips.

Faulkner, Raymond Oliver (1973), The Ancient Egyptian Coffin Texts I:Spells 1-354, Warminster: Aris\& Philips.

Faulkner, Raymond Oliver (1969), The Ancient Egyptian Pyramid Texts, Oxford: Clarendon Press.

Foster, John Lawrence (2001), Ancient Egyptian Literature: an Anthology, Texas:University of Texas Press.

Gasse, Annie (1996), Les sarcophages de la troisième période intermédiaire du Museogregorianoegizio, AegGreg3, Vatican City: Monumenti, musei e galleriepontificie.

Gauthier, Henri et Lefebvre Gustave (1923), « Sarcophages du Moyen Empire provenant de la nécropole d'Assiout », ASAE 23, Le Caire: IFAO, pp. 1-33.

Gauthier, Henri (1925-1931), Dictionnaire des noms géographiques contenus dans les textes hiéroglyphiques I-VII, Le Caire: IFAO.

GOYON, Jean-Claude (1975), Textes mythologiques II. « Les révélations du mystère des Quatre Boules », BIFAO 75, Le Caire, IFAO, pp. 349-399.

Hart George(2005), The Routledge Dictionary of Egyptian Gods and Goddesses, $2^{\text {nd }}$ ed. London: Routledge.

Hayes, William Christopher (1939), The burial chamber of the treasurer Sobk-moser from ErRizeikāt, Papers 9, New York: The Metropolitan Museum of Art.

Helck, Wolfgang (1957), Urkunden der 18. Dynastie. Heft 19, HistorischeInschriftenThutmosis' IV. undbiographischeInschriften seiner Zeitgenossen, Urk. 4, Urk. der 18. Dynastie 4, Bd. 5, Berlin: Akademie-Verlag.

James P. Allen et alii(1999), L'art égyptien au temps des pyramides, Paris: Réunion des musées nationaux.

Josephson, Jack A. and Eldamaty, Mamdouh Mohamed (1999), Statues of the XXV ${ }^{\text {th }}$ and XXVI ${ }^{\text {th }}$ Dynasties, CGC Nos 48601-48649, Cairo: The Supreme Council of Antiquities Press.

Junge, Friedrich (1987), Elephantine XI: Funde und Bauteile, ArchVer 49, Mainz: Ph. von Zabern.

Junker, Hermann (1939), « Pḥrnfr», ZÄS 75, Leipzig: J.C. HINRICHS VERLAG, pp. 63-84.

Junker, Hermann (1958), Der grosse Pylon des Tempels der Isis in Philä. mitZeichnungen von Otto Daum, Wien: In Kommissionbei Rudolf M. Rohrer.

Junker, Hermann (1934), Gîza. II: Berichtüber die von der Akademie der Wissenschaften in Wien auf gemeinsameKostenmit Dr. Wilhelm PelizaeusunternommenenGrabungen auf demFriedhof des AltenReichesbei den Pyramiden von Gîza. Band II: Die Mastabas der beginnenden V. Dynastie auf demWestfriedhof, Akademie der Wissenschaften in Wien. Philosophisch-historischeKlasse 70/1, Wien; Leipzig: Hölder-Pichler-Tempsky A. G.

Kamal Ahmed bey (1916), «Fouilles à Deir Dronka et à Assiout (1913-1914) », ASAE 16, Le Caire: IFAO, pp. 65-114.

Kamāl, Aḥmad (1904-1905), Stèles ptolémaiques et romaines, CGC Nos 22001-22208, Le Caire: IFAO.

Kitchen, Kenneth Anderson (2014), Ramesside Inscriptions. Translated \& Annotated: Translations VII, Malden; Oxford: Wiley-Blackwell. 
Kitchen, Kenneth Anderson (1986-1989), Ramesside Inscriptions: Historical and Biographical VII, Oxford: B. H. Blackwell.

Koefoed-Petersen, Otto (1951), Catalogue des sarcophages et cercueils égyptiens [traduit du manuscrit danois par France Gleizal en collaboration avec l'auteur], PGNy Carlsberg 4, Copenhague: Bianco LunosBogtrykkeri.

Kurth, Dieter (2014), Edfou VI, Die Inschriften des Tempels von Edfu. Abteilung 1, Übersetzungen 3, Gladbeck: PeWe-Verlag.

Kurth, Dieter (1998), EdfouVIII, Die Inschriften des Tempels von Edfu. Abteilung 1, Übersetzungen 1, Wiesbaden: HarrassowitzVerlag.

Leitz Christian(2002), Lexikon der ägyptischenGötter und Götterbezeichnungen. Vol. I-VII, OLA 110-116, Leuven; Paris; Dudley: Peeters.

Leitz Christian(2003), Lexikon der ägyptischenGötterundGötterbezeichnungen. Vol. VIII, Register, OLA 129, Leuven; Paris; Dudley: Peeters.

Leitz, Christian (1994), Tagewählerei: das Buch ḥ3t nḥḥph.wyd̂t und verwandteTexte I, ÄgAbh 55, Wiesbaden: HarrassowitzVerlag.

Le Page Renouf, Peter and Naville, Edouard (1904), The Egyptian Book of the Dead: Translation and Commentary, London : The Society of biblical archæology.

Lepsius, Richard (1849), Denkmäleraus ̈̈gypten und Äthiopien: Nach den Zeichnungen der von Seiner MajestätdemKönige von Preussen Friedrich Wilhelm IV :nachdiesenLänderngesendeten und in den Jahren 1842-1845, ausgefuhrtenWissenschaftlichen Expedition: Auf BefehlSeinenMajestät.ZweiteAbtheilung:Denkmäler des altenreichs, Berlin: NicolaischeBuchhandlung.

Mariette, Auguste(1889), Les mastabas de l'ancien empire: fragment du dernier ouvrage de A. Mariette / publié d'après le manuscrit de l'auteur par G. Maspero, Paris: F. Vieweg.

Maspero, Gaston, Sarcophages des époques persane et ptolémaïque. Tome premier, $1^{\mathrm{er}}$ fasc., CGC Nos 29301-29303, Le Caire: IFAO, 1908.

Monnet, Janine, « Les briques magiques du Musée du Louvre », RdÉ 8 (1951), Paris: imprimerie nationale, 1951, pp. 151-162.

Morgan, Jacques de et alii (1895), Catalogue des monuments et inscriptions de l'Égypte antique. Première série, Haute Égypte. Tome second, Kom Ombos. Première partie, Vienne: Adolphe Holzhausen, imprimeur de la cour I. \& R. et de l'université.

Naville, Edouard (1892), The festival-hall of Osorkon II. in The great Temple of Bubastis, EES 10, London: K. Paul, Trench, Trübner.

Naville, Edouard (1901), The temple of Deir El Bahari. Part IV, The shrine of Hathor and the southern hall of offerings: Plates LXXXVII-CXVIII, EEF XIX, London: EEF.

Osing, Jürgen (1998), HieratischePapyri ausTebtunis I. The Carlsberg papyri 2, CNI publications 17: Copenhagen: The Carsten Niebuhr Institute of ancient Near Eastern studies: University of Copenhagen, Museum Tusculanum Press.

Perdu, Olivier and Rickal, Elsa (1994), La collection égyptienne du Musée de Picardie, Paris: Réunion des musées nationaux; Amiens: Musée de Picardie.

Piankoff, Alexandre(1942), Le livre du jour et de la nuit: avec un chapitre sur l'écriture énigmatique par Étienne Drioton, BiÉtud 13, Le Caire: IFAO.

Redford Donald B.(2001), The Oxford encyclopedia of Ancient Egypt. Vol. I-III, Oxford; New York; Paris: Oxford University Press. 
Reisner, George Andrew(1942), A History of the Giza necropolis I, Cambridge: Harvard University Press.

Rochemonteix, Maxence de and Chassinat, Émile (1987), Le temple d'Edfou I. 3.Deuxième édition revue et corrigée par Sylvie Cauville et Didier Devauchelle, MMAF 10, Le Caire: IFAO.

Rochemonteix, Maxence de andChassinat, Émile (1984), Le temple d'Edfou I, 1. Deuxième édition revue et corrigée par Sylvie Cauville et Didier Devauchelle, MMAF 10, Le Caire: IFAO.

Schott, Siegfried (1929), UrkundenmythologischenInhalts. Heft 1: Bücher und Sprüchegegen den Gott Seth, Urkunden des ägyptischenAltertums 6, Leipzig: J. C. Hinrichs.

Scott, Gerry D. (1986), Ancient Egyptian art at Yale, New Haven (Conn.): Yale university art gallery.

Seele, Keith Cedric (1959), The Tomb of Tjanefer at Thebes, Chicago, Illinois: University of Chicago press, OIP 86.

Sethe, Kurt Heinrich (1960), Die AltägyptischenPyramidentexte: nach den Papierabdrücken und Photographien des Berliner Museums, Darmstadt: WissenschaftlicheBuchgesellschaft; [puis] Hildesheim: G. Olms.

Speleers, Louis (1923), Recueil des inscriptions égyptiennes des Musées royaux du cinquantenaire à Bruxelles, Bruxelles: Maison d'Edition I. Vanderpoorten.

Spiegelberg, Wilhelm (1906-1908), Die demotischenDenkmäler. 2, Die demotischen Papyrus, CGC Nos 30601-31270, 50001-50022, Strassburg: M. Dumont.

The Epigraphic survey (in cooperation with the Department of Antiquities of Egypt) (1980), The tomb of Kheruef: Theban Tomb 192, OIP 102, Chicago; Illinois: The Oriental Institute of the University of Chicago.

Thiem, Andrea-Christina (2000), Speos von Gebel es-Silsileh: Analyse der architektonischen und ikonographischenKonzeptionimRahmen des politischenunglegitimatorischenProgrammes der Nachamarnazeit, ÄAT 47, Wiesbaden: Harrassowitz.

Vercoutter, Jean (1962), Textes biographiques du Sérapéum de Memphis: contribution à l'étude des stèles votives du Sérapéum, BEHE. 4 e section: sciences historiques et philologiques 316, Paris: Librairie ancienne Honoré Champion.

Verhoeven, Ursula(1993), Das saitischeTotenbuch der Iahtesnacht: P. Colon. Aeg. 10207 I-3, Teil 1: Text/ miteinemBeitrag von Peter Dils; Teil 2: HieroglyphischeTranskription und Tafeln; Teil 3: Beilagen,PapyrologischeTexte und Abhandlungen 41, Bonn: R. Habelt.

Vernus, Pascal (1978), Athribis: textes et documents relatifs à la géographie, aux cultes et à l'histoire d'une ville du delta égyptien à l'époque pharaonique, Bibliothèque d'étude 74 , Le Caire: IFAO.

Wildung, Dieter(1972), «Two Representations of Gods from the Early Old Kingdom »,MiscellaneaWilbouriana I, Brooklyn: The Brooklyn Museum, pp. 145-160.

Wildung, Dietrich (1969), Die Rolle ägyptischerKönigeimBewusstseinihrerNachwelt I, MÄS 17, Berlin: B. Hesslin.

Wilkinson Richard H. (2003), The Complete Gods and Goddesses of Ancient Egypt, New York: Thames \& Hudson. 